\title{
Zdzisław Komosiński
}

\section{Próby osiedlenia się zakonu braci mniejszych kapucynów na Śląsku w XVII wieku}

Prawo Kanoniczne : kwartalnik prawno-historyczny 18/3-4, 195-243

1975

Artykuł został zdigitalizowany i opracowany do udostępnienia w internecie przez Muzeum Historii Polski w ramach prac podejmowanych na rzecz zapewnienia otwartego, powszechnego i trwałego dostępu do polskiego dorobku naukowego i kulturalnego. Artykuł jest umieszczony w kolekcji cyfrowej bazhum.muzhp.pl, gromadzącej zawartość polskich czasopism humanistycznych i społecznych.

Tekst jest udostępniony do wykorzystania w ramach dozwolonego użytku. 
O. ZDZISEAW KOMOSIŃSKI OFM CAP.

\section{PROBY OSIEDLENIA SIE ZAKONU BRACI MNIEJSZYCH KAPUCYNOW NA SLA SKU W XVI WIEKU}

Tresc: Wstęp. - I. Kapucyni na Sląsku w czasie wojny trzydziestoletniej. - II. Starania biskupa pomocniczego wrocławskiego Baltazara Liescha o zdobycie dla kapucynow fundacji w Prudniku. - III. Grupa misjonarzy kapucyńskich bada możliwosci osiedlenia się w Prudniku i Nysie. - IV.Kapucyńscy misjonarze badają możliwości osiedlenia się we Wrocławiu, Zielonej Górze i Sławie. - Zakończenie.

\section{Wstęp}

Dotychczasowa historiografia zakonu kapucynów na Sląsku jest uboga i tylko popularna. Pomimo, że kapucyni na Sląsku osiedlili się na stałe w 1654 roku i działali przez 156 lat (do 1810), dzieje ich nie doczekały się naukowego opracowania. Przebywali jednak kapucyni na Sląsku już wcześniej. Od roku 1629-1654 na terenach tych poszukiwali oni dogodnych warunków założenia klasztoru. Ich działalność $\mathrm{w}$ tym okresie - w różnych miastach śląskich - byla tylko tymczasowa. Prawo zakonne zabraniało kapucynom przebywać poza klasztorem, chyba z pomocą duszpasterską na krótkj czas.

Ponieważ w XVII wieku prowincja austriacko-czeska kapucynów otrzymywała wiele propozycji od fundatorów na założenie nowych klasztorów, dlatego proponowane fundacje na Sląsku, nie mogły być dużo gorsze od tych, które oferowano w innych częściach cesarskiego państwa Habsburgów. Zarząd prowincji bowiem - kierując się dobrem zakonu - wybierał placówki, które posiadały lepsze warunki i dawały gwarancję lepszych możliwości bytowania na przyszłość.

Opracowanie tego tematu stało się aktualne, zwlaszcza w obecnym czasie, gdy po przerwie 136 lat (1810-1946) kapucyni ponownie przybyli na Sląsk i podjęli działalność duszpasterską.

Większość archiwaliów o ówczesnych kapucynach śląskich zaginęła w czasie drugiej wojny światowej. $\mathrm{Na}$ podstawie jednak tego co się zachowało i fragmentarycznych przekazów z literatury można odtworzyć obraz życia i działalności pierwszych kapucynów na tych ziemiach. 
Artykuł oparty jest zasađniczo na źródłach archiwalnych. Autor podaje $w$ nim wiele szczegółów $z$ działalności kapucynów, by zobrazować w jak specyficznych i trudnych warunkach, wśród jakiej atmosfery religijnej i działań wojny 30-letniej, kapucyni usilowali osiedlic się na Sląsku.

\section{Kapucyni na Sląsku w czasie wojny trzydziestoletniej ${ }^{1}$}

Protestantyzm na Śląsku rozwijał się szybko i intensywnie. Po stu latach cd reformacji Marcina Lutra - Sląsk był prawie całkowicie objęty przez wyznania protestanckie. Wiarę katolicką wyznawaly tylko nieliczne jednostki. Ziemie te pod względem politycznym podległe były władcom Austrii.

Cesarz Ferdynand II postanowił w 1628 r. rozpocząc rekatolizację Sląska czyli kontrreformacje. Przeprowadzenie tej akcji zostało powierzone generałowi broni Karolowi Hannibalowi z Dohnau. Kontrreformację Sląska rozpoczęto więc pod koniec roku 1628 przy pomocy oddzialów wojskowych generała Karola Hannibala z Dohnau i regimentu Lichtensteina. Ta akcją najpierw objęto na Dolnym Sląsku księstwo glogowskie; na Górnym S̉ą̨sku (28 grudnia 1628 r.) księstwo opawskie (Troppau). Od początku roku następnego działalnością tą objęto resztę Sląska ${ }^{2}$.

Pierwszy okres wojny trzydziestoletniej przyniósł sukcesy cesarzowi i katolikom, dlatego cesarz Ferdymand II (1619-1637) i jego sławny generał, Wallenstein, pragnęli jak najszybciej wyciągnąc korzyści ze swych zwycięstw przez odebranie książętom i miastom protestanckim majątków, które dała im reformacja.

Po zawarciu w dniu 6 marca 1629 r. pokoju w Lubece zostal wydany „edykt restytucyjny”, na mocy którego majątki sekularyzowane po 1552 roku, a należące do arcybiskupstw, biskupstw, klasztorów i kościołów, przechodziły z powrotem w rece katolików. Przywrócone też zostaly wszystkie przywileje i władza sądowa biskupów. Edykt miał zostać wprowadzony w życie przez cesarskich komisarzy, korzystających z ochrony wojskowej ${ }^{3}$.

W tymże roku w większej części Górnego Sląska na rozkaz cesarski katolikom z powrotem zwróconю kościoły, usunięto predykantów, a na ich miejsce zostali ustanowieni katoliccy proboszczowie 4.

Brama dla kontrreformacji została na Slask otwarta. Misjonarze

1 W opisywaniu sytuacji na Sląsku zwróciłem szczególną uwagę na miejscowości, w których potem kapucyni założyli klasztory.

\& J. Chrzą s c z, Geschichte der Stadt Neustadt. Neustadt 1912 s. 171 n.

s Akademia Nauk ZSRR, Historia Powszechna. T. IV. Warszawa 1967 s. 806.

4 J. C h r z a s z c z, dz. cyt., s. 178. 
nie narażali już życia, idąc $\mathrm{w}$ kraj protestancki, bo chroniły ich oddziały wojskowe i władza państwowa. Urzędy obsadzane były ponownie katolikami.

Już od 1629 roku na Sląsk udawali się misjonarze kapucyńscy z prowincji austriacko-czeskiej. Przełożeni wysyłali ochotników 5 .

Dnia 10 września 1629 r., katolickie wojsko szturmem zdobyło Zieloną Górę ${ }^{6}$.

W połowie października 1629 r. przyjechał do Zielonej Góry biskup Baltazar Liesch i poświęcił kościól, by można w nim bylo odprawiać religijne obrzędy katolickie. W mieście byli wówczas jezuici.

W lecie 1630 roku powstała w mieście zaraza. Rozszerzyła się szybko. Smiertelność była bardzo wielka. W ciągu roku z 10.000 mieszkańców zmarło 7000. Na jednej z ulic wymarli wszyscy mieszkańcy ,ulicę tę nazwano ulica Zmarłych (Totengasse); nazwa ta przetrwała do 19 wieku. Wybuchł również pożar, który spalił jedną trzecią miasta; szczególnie zniszczone zostały przedmieścia. W tym roku jezuici opuścili miasto i przekazali duszpasterstwo kapucynom ${ }^{7}$. Kapucyni podjęli pracę $w$ bardzo trudnych warunkach. Opiekując sie chorymi w czasie zarazy, szerzyli szczególnie kult do Matki Boskiej. Odmawiali przy chorych modlitwę do Bogarodzicy w celu odwrócenia zarazy ${ }^{8}$. O tej ich ofiarnej pracy pozostało nam nieco szczegółćw.

W 1631 r. w Zielonej Górze pracowało dwóch kapucyńskich misjonarzy. O. Franciszek ze Sląska głosił słowo Boże. Tym, którzy nie przychodzili na jego kazania, niósł prywatnie słowa napomnienia i zachęty. O. Atanazy z Valdenone, mlody kapłan, uczył młodzież. Podówczas w Zielonej Górze i w okolicy panowała zaraza. W pracy nad niesieniem pomocy duchownej dla chorych i konajacych, nie brakowało kapucynów, którzy nie zważając na własne niebezpieczeństwo, niezmordowanie pracowali przy chorych: nawiedzali ich $w$ domach, pocieszali i umacniali $w$ wierze, bliskich śmierci zaopatrywali sakramentami świętymi, przy konających modlili się, zmartych grzebali.

Wkrótce c. Atanazy zaraził się ciężką chorobą. Opatrzony sakramentami świętymi przez o. Franciszka, zmarł dnia 6 czerwca $1631 \mathrm{r}$.

5 Annales Capucinorum, Liber seu Protocollum totius provinciae Boemo-Austriacae, Styriacae Ordinis Rratrum Minorum Capucinorum Praha-Strahov. Bibliotheca Nationalis. T. III. $1653 \mathrm{nr} \mathrm{80,} \mathrm{s.} 185$ (skrót: A.C.).

$\rightarrow \mathrm{O}$. W $\mathrm{i} f \mathrm{f}$ Geschichte der evangelischen Stadt und Landgemeinde Grünberg in Niederschlesien. Grünberg 1841 s. 56 n.

7 Tamże s. $57 \mathrm{n}$.

8 Stella coeli extirpavit, quae lectavit Dominum, mortis pestem, quam plantavit primus parens hominum."...

Tamże s. 58. Por. Preces quotidianae provinciae cracoviensis Ord. Min. Capuccinorum. Cracoviae 1937 s. $18 \mathrm{n}$. 
Pochowany zostal w podziemiach kościoła parafialnego w pobliżu wielkiego oltarza ${ }^{9}$.

Po jego śmierci o. Franciszek nie opuścił miasta i chorych, pracując nadal pomimo osamotnienia 10.

W tym czasie generał Karol Hannibal z Dohnau powziął decyzję bzwlocznego sprowadzenia kapucynów na stałe do Wrockawia i dokonania erekcji klasztoru w metropolii Sląska. W tym celu poszukiwal on zarówno w mieście, jak i na przedmieściach odpowiedniej parceli do zbudowania klasztoru. Znalazł w koncu miejsce odpowiednie, położone poza rzeką Odrą, dość daleko od centrum miasta, na przedmieściu zwanym Elbing. ${ }^{11}$

Miejsce to, a mianowicie dom i ogród, nabył za własne pieniądze, postarał się również o odpowiednie dokumenty kupna i sprzedaży i posiadłość tę przeznaczył na klasztor kapucyński. Parcela byla opustoszała i rozległa, rozciągała się aż do mostu na rzece Odrze. Hrabia nie szczędził pieniędzy z własnej skarbony, by możliwie jak najprędzej przygotować wszystko do przyszłej budowy. Polecił zwieźć na plac kamienie, budulec i inne materiały konieczne do budowy. Wysłał swoich majstrów i strażników dla przygotowania wszystkiego tak, aby w najkrótszym czasie można było wznieść klasztor. Do przyspieszenia realizacji dzieła bardzo przyczyniła się obecność kapucynów, których roztropność i bogobojność robiły na fundatorze dobure wrażenie. 12

Wojna religijna nie była jednak zakończona. Książkę saski i król szwedzki zawarli przymierze, a ich protestanckie wojska wkroczyły na tereny cesarza Ferdynanda II. Książę saski planowal zajęcie Sląska. Sytuacja taka wyrwołała wśród ludności, a zwłaszcza katolików, przerażenie i niepokój. Wielu potajemnie opuszczało Sląsk, ưdając się do Austrii. W'́ród nich był również hrabia Hannibal z Dohnau, który w tymże roku uszedł do Pragi. Sląsk zajmowały wojska protestanckie: saskie, duńskie i szwedzkie. Rozpoczęły się prześladowania katolików, niszczono kościoły, pustoszono kraj.

Sytuacja dla katolików stała się niebezpieczna, a dla duchownych katolickich - wprost beznadziejna. Wobec siły obcych wojsk i ciągłego niebezpieczeństwa śmierci ze strony sfanatyzowanych protestantów - praca misjonarzy stała się niemożliwa. Po wyjeździe z Wrocławia generała Hamnibala z Dohnau, kapucyni nie mieli wystarczających środków utrzymania, a brak opieki wojskowej stwa-

- A. C., t. I. 1631 nr 26, s. 489. Por. A. C., t. III. 1654 nr 55, s. 282.

10 A. C., t.I. $1631 \mathrm{nr} 27$, s. 489.

11 Tamże s. 490 . Por. H. M a r kgraf, Die Strassen Breslaus nach ihrer Geschichte und ihrer Namen. Breslau 1896 s. 39 . „Wies Olbin znajdowała się w rejonie kościoła św. Michała przy obecnej ulicy Nowowiejskiej... Nazwa Olbin ustaliła się z czasem dla całego sąsiedniego terenu". Por. Z. A n tk owiak, Ulice $i$ place Wroctawia. Wroclaw $1970 \mathrm{~s} .180$.

12 A. C., t. I. $1631 \mathrm{nr} 27$, s. 490. 
rzał obawy utraty życia. Dlatego w większości wrócili do Austrii ${ }^{13}$.

W 1632 r. wojska saskie i szwedzkie zajęły okolice Wrocławia. W posiadaniu ich znalazły się przedmieścia Wrocławia aż po wyspę Tumską i wyspę Piaski włącznie. Nieprzyjacielskie wojska przebywały tam aż do 1635 r. ${ }^{14}$. We władaniu ich znalazła się również posiadłość kapucynów.

W Pradze hrabia Karol Hannibal podupadł na zdrowiu. Sporządził więc testament. Spostrzegl jednak wkrótce, że w testamencie nic nie zapisał kapucynom, którym nie tylko obiecał zbudować klasztor we Wrocławiu, lecz nawet zobowiązał się do tego ślubem. Sporządził więc dnia 18 lutego 1633 r. kodycyl do testamentu. Kapucynom podarował ogród i wszystkie swoje domy we Wrockawiu oraz wszystkie materiały przygotowane do budowy. Ponadto dal im dziesięć tysięcy talarów cesarskich.

Wkrótce po tym generał Karol Hannibal z Dohnau zmarł. Kapucyni jednak ze zrealizowaniem legatu tego wielkiego fundatora musieli poczekać do bardziej pomyślnych czasów 15 .

Na skutek więc działań wojennych do erekcji klasztoru we Wrocławiu nie doszło.

W roku 1630 pracował w Głogowie przy kościele parafialnym św. Mikołaja ojciec kapucyn Baltazar Schetze 16. Ponieważ w Głogowie było wielu duchownych, dlatego $\mathrm{w}$ czasie zarazy o.Baltazar wyjeżdżał do Zielonej Góry z pomocą duszpasterską ${ }^{17}$.

Gdy skończyła się w Zielonej Górze zaraza, miasto nie posiadało duszpasterza. O.Franciszek udał się do Wrocławia, gdzie go wezwał burgrabia Hannibal z Dohnau. Obywatele z Zielonej Góry znali o. Baltazara, który się odznaczał wielką troską o dusze ludzkie. Rada miejska zwróciła się 16 czerwica 1632 r. do biskupa wrocławskiego - Karola Ferdynanda (który był królewiczem polskim), aby zechciał zatwierdzić zaprezentowanego przez nich o.Baltazara Schetzego, kapucyna, na proboszcza w Zielonej Górze 18. Wprawdzie prośba została pozytywnie załatwiona, jednak okoliczności polityczne nie były sprzyjające, by o.Baltazar mógł zaraz objąć w posiadanie urząd proboszcza.

Księstwem glogowskim rządzil wówczas wódz cesarski Wallenstein. Byl on przeciwny takim sposobom kontrreformacyinym, jakie stosowano $\mathrm{w}$ cesarstwie tzn. bezwzględnego zabraniania protestantom kultu religijnego. Nie faworyzował więc katolików w Zielonej

13 A. C., t. I. $1631 \mathrm{nr} 28$, s. $490 \mathrm{n}$.

$14 \mathrm{H}$. Markgraf, Geschichte Breslaus in kurzer Ubersicht. Breslau $1888 \mathrm{~s} .27$.

15 A. C., t. II. $1633 \mathrm{nr} 1$, s. $530 \mathrm{n}$.

$16 \mathrm{H}$. Schmidt, Geschichte der Stadt Grünberg Schles. Grünberg 1922 s. 103.

17 O. W ol f f, dz. cyt., s. 58.

18 Tamże s. 60. 
Górze. Poprzestał tylko na żądaniu, by katolicy z Zielonej Góry podali swoją listę. Katolicy nauczeni jaki ciężki los spotyka ich, gdy miasto dostaje się $w$ ręce wojsk protestanckich, zgłosili się tylko w liczbie 14. Ponieważ protestantom Wallentein pozostawil całkowitą swobode wyznania, dlatego chętnie skorzystali oni z tej okoliczności i do Zielonej Góry przywołali z wygnania swego pastora Nippego, który, przebywał w Torgau.

W 1632 roku w sierpniu powróciły do księstwa glogowskiego wojska: saskie, brandeburskie i szwedzkie pod dowództwem saskiego generala Arnheima, a dnia 6 sierpnia zdobyły one twierdzę Głogów. Wśród protestanckich wojsk znajdowal się ich kapelan - pastor Willich. Odprawiał on nabożeństwa dla ludności protestanckiej, organizował gminę oraz przywracal na urzędy wydalonych predykantów. Dnia 26 sierpnia przybył Willich z Glogowa do Zielonej Góry, adebrał katolikom kościół parafialny, poświęcił go w sposób uroczysty do celów protestanckich. Wszystkie katolickie przedmioty z kościcła wyrzucił. W sierpniu 1632 r. Wrócił do Zielonej Góry Polski Diakon - Melchior Triebskorn 19. Pastor Nippe, ponieważ sam byl już w podeszłym wieku, dnia 3 marca $1633 \mathrm{r}$. ustanowil swoim następcą diakona Jana Chryzostoma Nebiliusa. W ten sposób w Zielonej Górze pracowało trzech duchownych protestanckich, a nie było duchownego katolickiego.

Gdy zbliżały się wojska szwedzkie do Zielonej Góry, radcy miejscy, którzy przeszli na katolicyzm, musieli uchodzić z miasta. Przekroczyli oni granicę szukając schronienia $w$ Polsce. $Z$ apostatami bowiem, którzy $z$ protestantyzmu przeszli na wiarę katolicką, o wiele gorzej się obchodzono niż z tymi, którzy w katolicyźmie się urodzili 20

Z kolei dnia 16 lutego 1633 r. do Zielonej Góry weszły katolickie wojska austriackie. Ponieważ jednak zupełnie nie mieszały sie do spraw religijnych, dlatego katolicy nie odważyli się dochodzic swoich praw i nie wzywano $z$ Polski tych katolickich obywateli, ktcrzy tam się schronili. Gdy dnia 12 października 1633 r. wkroczyła na Sląsk armia Wallenteina, by uwolnić te ziemie $\mathrm{z}$ wrogich wojsk jednak sam Wallenstein, coraz bardziej skłaniający się do protestantów, popierał ich religie.. Protestanccy obywatele Zielonej Góry otrzymali od niego 29 października 1633 r. dokument, zapewniający swobodne wyznawanie religii.

Sytuacja dla katolików zmieniła się dopiero wówczas, gdy 25 lutego 1634 roku zginął Wallenstein. Na jego miejsce gubernatorem księstwa głogowskiego został hrabia Jerzy z Oppersdorf, przyjaciel jezuitów. Ten zaraz po abjęciu władzy, wydał rozkaz zaprzestaniá w całym księstwie nabożeństw ewangelickich. Rozkaz wysłany do

19 Tamże.

20 Tamże s. 61. 
Zielonej Góry nakazywał katolikom zająć kościól, a protestanckim duchownym opuścić miasto. Kada miejska tym razem rozkazu nie usłuchała 21.

Gdzie przebywał o.Baltazar Schetze od chwili otrzymania nominacji na proboszcza - nie wiadomo. Dokładnie śledzil wypadki w księstwie glogowskim. Po kilku tygodniach od chwili objęcia władzy przez hrabiego Oppersdorfa, o.Baltazar wystaral się u carskiego komisarza $z$ Żagania (Sagan) o rozkaz nakazujący radzie miejskiej w Zielonej Górze, by mu przekazała kościół. Dnia 12 kwietnia 1634 r. o.Baltazar z tym pismem przy jechal do Zielonej Góry. Rada miejska uczyniła tylko tyle, że nakazała zamknąć kościół i nawet predykanci nie odprawiali w nim nabożeństw. Protestanci wysłali prośbę do Glogowa, by -- do czasu roztrzygnięcia przez cesarza sprawy parafialnego kościoła - mogli nabożeństwa odprawiać w polskim kościele św. Trójcy. Prośby tej nie przyjęto.

O.Baltazar z niczym wyjechał z Zielonej Góry. Ale już 15 kwietnia wrócił z powrotem i zażądał ponownie wydania kluczy od kościoła. Sytuacja wśród protestantów stała się napięta. W niedzielę Wielkanocy nie odbyło się $\mathrm{w}$ mieście żadne publiczne nabożeństwo. Wywołało to u protestantów rozgoryczenie, którego przyczynę przypisywali o.Baltazarowi. Zebrali się więc na naradę u burmistrza Marcina Zyrusa. Potem w sposób gwałtowny wyjaśnili o:Baltazarowi, że jego pretensje są bezprawne, nie może się bowiem wykazać odpowiednimi dokumentami, które by mu dawały upoważnienie do jego roszczeń. W pierwszy vięc dzień Wielkanocy zdołał o.Baltazar ledwie ujść z życiem z Zielonej Góry. Mieszczanie wysłali rezolucję do Głogowa, w której wytlumaczyli swoje zachowanie sie wobec o.Baltazara 22. Jeden z komisarzy cesarskich w Głogowie, Piotr Gebauer, odpisał im, że sprawa przedstawiała się w rzeczywistości inaczej aniżeli rada opisała. O.Bltazar Schetze zdołał opuścić Zieloną Górę $\mathrm{z}$ dużym niebezpieczeństwem utraty życia. Tylko dzięki temu wyjechał z miasta, że przecistawił, jakie konsekwencje i ciężkie kary groża im w razie gdyby go zgladzili.

O. Baltazar byl czlowiekiem nieustąpliwym. Dnia 20 kwietnia przyjechał znowu do Zielonej Góry, żądając kluczy do kościoła. Rada miejska dała mu pisemną decyzję, że kluczy powinien żądać od kościelnego. $\mathrm{Na}$ to o.Baltazar rie zgodził się. Obawial się podstępu; bał się sam odbierać kościoła, żądał̆, by mu rada miejska przekazała klucze w sposób formalny. Dnia 24 kwietnia o.Baltazar napisał list do pastora Nippego, w którym nazwał się proboszczem Zielonej Góry. ${ }^{23}$ Sam zaś nie odjeżdżal $z$ miasta i postanowil dochodzić swoich praw proboszczowskich drogą listową. Dnia 25 kwietnia 1634 r.

21 Tamże s. $62 \mathrm{r}$.

22 Tamże s. 63.

23 Tamże s. 64. 
wniósł zażalenie do rady miasta, na duchownych protestanckich. Rada miejska zwlekała z daniem odpowiedzi o. Baltazarowi. Ponieważ jednalk groził, że użyje przemocy, poleciła dnia 28 kwietnia, by pastor Nipe uwolnił plebanię. Nippe przeniósł się do prywatnego domu. Tylko tyle skorzystał o.Baltazar, że miał gdzie zamieszkać. Kluczy bowiem od kościoła nie otrzymał 24.

Tymczasem sytuacja polityczna zmieniła się. Dnia 3 maja 1634 r. wojska saskie pod dowództwem generała Arnheima wkroczyły na Sląsk i rozgromily pod Legnicą wojska cesarskie. 8 maja protestanci z powrotem otworzyli kościół, by sprawować normalne swoje nabożeństwa. Wkrótce wojska saskie wkroczyły do Zielonej Góry. Proboszcz katolicki w ochronie własnego życia musiał uchodzić z miasta tym razem nie na długo.

Pod murami Nördlin dnia 6 września 1634 r. armie: szwedzka, i niemiecka poniosły ad wojsk katolickich calkowitą klęską. Obie strony dążyły do pokoju, który został zawarty 30 maja $1635 \mathrm{r}$. w Pradze. Cesarz musiał zgodzić się na zawieszenie edyktu restytucyjnego na 40 lat. Protestanci mieli zachować ten stan posiadania dóbr duchownych, jaki istniał w 1627 roku ${ }^{25}$. Jednak zawieszenie edyktu objęło tylko księstwa: legnickie, brzeskie i oleśnickie oraz miasto Wroclaw. W nich zapewniono wolność religijną. Pozostała część Sląska, około trzy czwante, była nadal zależna całkowicie od woli cesarza.

Natychmiast więc po ustąpieniu $\mathrm{z}$ księstwa głogowskiego wojsk saskich protestanci utracili swoje kościoły. W listopadzie $1635 \mathrm{r}$. hrabia Jerzy Oppersdorf, gubernator księstwa głogowskiego, został również przewodniczącym komisji, której zadaniem bylo przywrócić kościoły katolikom we wszystkich miastach i wsiach. Komisja ta przybyła do Zielonej Góry dnia 12 grudnia 1635 r. Zażądała opuszczenia kościoła $\mathrm{i}$ 'w ciągu pięciu dni wysliedlenia predykantów. Katoliccy radni miasta, którzy w roku 1632 uciekli przed wojskami szwedzkimi do Polski, wrócilii teraz do Zielonej Góry i 14 grudnia 1635 roku objęli urzędy. W radzie miejskiej było tylko trzech protestantów. Do Zielonej Góry przybył również o. Baltazar Schetze. Tym razem bez trudności otrzymał klucze od kościoła. Dnia 18 grudnia 1635 r. przekazano mu paramenty kościelne, a w dniu następnym opróżniono mu plebanię i o.Baltazar rozpoczął swoją pracę duszpasterksą jako proboszcz ${ }^{26}$. Komisarze cesarscy czuwali nad przeprowadzaniem akcji kontrreformacyjnych.

Dnia 29 listopada 1637 r. ogłosił proboszcz Schetze z ambony rozkaz biskupa pomocniczego wrocławskiego, że każdy mieszkaniec miasta ma chodzić do kościoła parafialnego, w nim powinien chrzcić

${ }^{24}$ Tamże s. 65.

25 Wielka Historia Powszechna. T. V. cz. 2. Warszawa 1938 s. 137.

26 O. Wolff, dz. cyt., s. 67. 
dzieci, zawierać związek małżeński i komunikować. Dnia 3 grudnia tenże rozkaz zostal przybity na budynku rady miejskiej do publicznej wiadomości. Następnego dnia otrzymali predykanci z Głogowa kategoryczny rozkaz natychmiastowego wysiedlenia, z zagrożeniem użycia przemocy w razie nieusłuchania. Pastor Nippe tego samego dnia opuścił Zieloną Górę ${ }^{27}$. Przez dwa lata o. Baltazar Schetze pracowal w spokoju. Praca jego w tym czasie była bardzo owocna. Niedługo jednak trwał pokój na tych ziemiach.

W 1639 roku Szwedzi znowu wtargnęli na Sląsk. Dnia 9 lipca weszli do Zielonej Góry. Przez trzy dni trwało plądnowanie miasta. Wielu obywateli, przeważnie katolików, uciekało do Polski. Dnia 16 lipca katoliccy radcy opuścili miasto. Protestanci triumfowali. Szwedzki porucznik Zedlitz 15 września 1639 r. nakazal otworzyć kościół i odbywać w nim ewangelickie nabożeństwa. Wkrótce wybrano nową radę miejską złożoną $z$ protestantów 28 .

Od tego czasu kończą się informacje o osobie o.kapucyna Baltazara Schetzego. Do Zielonej Góry na urząd proboszcza już nie wrócił. Brak materiałów nie pozwala stwierdzić, czy wrócil do prowincji zakonnej. Mógł też zginąć z rąk protestantów.

\section{Starania biskupa pomocniczego wrockawskiego Baltazara Liescha o zdobycie dla kapucynów fundacji w Prudniku}

$\mathrm{Na}$ ziemiach śląskich szalała wojna 30-letnia. Na lepsze czasy i zakończenie wojny czekali nie tylko kapucyni - cała bowiem Europa czekała na pokój. Kres tych religijnych zmagań nastąpił dopiero po zawarciu pokoju westfalskiego, tj. w 1648 r. Liczba ludności na Sląsku z powodu wojny zmniejszyła się w stosunku do stanu sprzed 30 lat przeciętnie o $20 \% 29$.

$\mathrm{Na}$ Sląsku odczuwało się duży brak księży. Katolicka szlachta śląska poszukiwała duchownych do przeprowadzania rekatolizacji kraju. Zastanawiano się, jaki zakon będzie mógł najlepiej pracować w tych trudnych warunkach, wśród zubożałej ludności. Uznano, że najlepiej do tego zadania nadadzą się zakonmicy kapucyni ${ }^{30}$.

W tym czasie kapucyni prowadzili w Austrii ożywioną działalność duszpasterską, zwłaszcza wśród protestantów. W $1653 \mathrm{r}$. kapucyni z prowincji austriackiej nawrócili na wiarę katolicką 17.400 protestantów ${ }^{31}$.

W trosce o rozszerzanie katolicyzmu na Sląsku szlachta śląska

27 Tamże s. 73.

28 Tamże s. 74.

${ }^{80} \mathrm{Z}$. W ó j cik, Historia Powszechna. T. III. Warszawa 1968 s. 350.

30 A. C., t. III. $1653 \mathrm{nr} 80$, s. 186.

${ }_{31} \mathrm{M}$. Heim bu cher, Orden und Kongregationen der katholischen Kirche. Bd I. Paderborn 1933 s. 741. 
zwróciła się do cesarza Ferdynanda III z prośbą o zakon kapucynów, jako najbardziej nadający się do dzieła nawracania ludu protestanckiego. Otrzymała ona zgodę na sprowadzenie kapucynów i poparcie cesarza u zakonnych władz kapucyńskich w 1653 roku ${ }^{32}$.

W tym czasie wladca księstwa opolsko-raciborskiego by 1 Karol Ferdynand - książę polski i szwedzki, biskup wrocławski i płocki. Ponieważ książę stale przebywał w Polsce, rządy obydwóch księstw powierzy 1 gubernatorowi - Jerzemu Maksymilianowi hrabiemu z Hoditz, który swą władzę gubernatorską sprawował w Prudniku ${ }^{33}$.

Zeby sprawy duchowne diecezji wrocławskiej nie ponosiły szkody $z$ powodu braku na miejscu pasterza, biskup Karol Ferdynand przekazał zarządzanie diecezją biskupowi pomocniczemu Janowi Baltazarowi Lieschowi z Hornau. Biskup Liesch, bogaty i nadzwyczaj gorliwy, nie szczędził sił $\mathrm{i}$ funduszów $\mathrm{z}$ własnych dóbr, byle tylko szerzyć wiarę katolicką $w$ diecezji wrocławskiej. On to przejął się wielce sprawą sprowadzenia kapucynów na Sląsk. Na Sląsku działali wówczas dwaj magnaci katoliccy, którzy z zadowoleniem przyjęli myśl sprowadzenia kapucynów na Sląsk: Jan Franciszek, baron z Fernemond, gubernator księstwa glogowskiego i Jerzy Maksymilian hrabia $z$ Hoditz, gubernator księstwa opolsko-raciborskiego. ${ }^{34}$ Biskup Liesch wspólnie $\mathrm{z}$ nimi naradzał się więc nad wyborem miejscowości, w której należałoby założyć pierwszy klasztor. Przyjęto propozycje hrabiego Hoditza, by pierwszy klasztor kapucynów zlokalizować w Prudniku.

Biskup Liesch i hrabia Hoditz zamierzali zwrócić się o zakonnych kapłanów do kapucynów prowincji austriacko-czeskiej.

Prudnik (Neustadt), jest to miasto leżące na Górnym Sląsku, na wzniesieniu, nad strumieniem Prądnik. Do 1708 roku nosilo nazwę Polnische-Neustadt. Od Nysy jest oddalone o 28 kilometrów ${ }^{35}$.

Dzieło rekatolizacji Prudnika rozpoczęło się z początkiem $1629 \mathrm{r}$. Wówczas to jeszcze generał Karol Hannibal z Dohnau wysłał do Prudnika oddział konny pod komenda kapitana La Mordi. Pod naciskiem kapitana i jego oddziału rada miejska uchwalika, by pastor Tilesius i wikary Simonius opuścili miasto. Protestanccy duchowni wyjechali z Prudnika 12 lutego $1629 \mathrm{r}^{36}$. Dzieło kontrefor-

\$2 A. C., t. III. $1653 \mathrm{nr} 80$, s. $185 \mathrm{n}$.

33 A. C., t. III. $1654 \mathrm{nr} 42$, s. 254.

84 A. C., t. III. $1653 \mathrm{nr} 81$, s. 186. Por. J. C h r z a s z c z, dz. cyt., s. 200. Por. A. Welt z el, Geschichte der Stadt Neustadt. Neustadt 1870 s. 683. ${ }_{35}$ Neustadt - na Śląsku było pięć miejscowości o tej nazwie; by nie było wątpliwości, o którą miejscowość chodzi podano współrzędne geograficzne: pod $50^{\circ} 15$ szer. geogr. póln. i $17^{\circ} 34^{\prime}$ dług. wsch. od Greenwich. Zob. Schlesisches Ortschaftsverzeichnis. Breslau 1941 s. 259 Por. Stownik Geograficzny Królestwa Polskiego. T. IX. Warszawa 1888 s. 26-28. Por. E. M a I iszew ski, Podręczny Stownik Geograficzny. Warszawa 1927 s. 316. Por. A. C., t. III. 1654 nr 40 , s. 251.

36 J. Ch r z ą s c z, dz. cyt., s. 174 n. 
macji bylo początkowo przeprowadzone przy pomocy oddziałów wojskowych, dopiero gdy wojsko zdołało zapewnić osobiste bezpieczeństwo misjonarzom mogli kapłani katoliccy rozpocząć swoją misyjną działalność.

Z początkiem drugiej połowy XVII wieku rekatolizacja w Prudniku była zadorwalająca. 26 października 1651 roku na polecenie biskupa odbyła się wizytacja w parafii Prudnik, dokonana przez kanonika Waltera. W sporządzonym sprawozdaniu powizytacyjnym nie podano liczby katolików i protestantów. Ten stan słabego zainteresowania się duszpasterstwem należy tłumaczyć slabym zdrowiem proboszcza Frosa. Zmarł on 27 grudnia 1651 r. Następnym proboszczem był Grzegorz Hilner z Rosenbach ${ }^{37}$. Ten usiłował powiększyć liczbę katolików. W drugim roku swojej pracy duszpasterskiej aktywnie wspomagał biskupa pomocniczego Liescha w jego zamiarze sprowadzenia do Prudnika kapucynów.

Biskup Liesch widząc, że istnieją realne możliwości sprowadzenia zakonników dzięki poparciu ze strony władz świeckich i szlachty, zwrócil się do biskupa wrocławskiego o zezwolenie na wprowadzenie do diecezji wrocławskiej kapucynów.

Biskup Liesch, po otrzymaniu zgody od biskupa Irarola Ferdynanda, zwrócił się z kolei z prośbą do Stolicy Apostolskiej o zezwolenie na sprowadzenie kapucynów na Sląsk. Papiez Innocenty X wysłał list dnia 18 maja 1653 roku, w którym pochwalił ów zamiar, zachęcił do wykonania go i zalecił by mimo trudności, które staną na drodze do realizacji owego dzieła, od wykonania jego nie odstąpić - na co dał swoje papieskie błogosławieństwo ${ }^{38}$.

W 1653 roku do Prudnika przybył biskup Liesch, by wraz z gubernatorem hrabią Hoditzem wybrać parcelę na osiedlenie kapucynów. Prostanowili oni przeznaczyć na ten cel parcelę Łukasza Sauera, protestanta, tj. dom, który dotąd przez miejscową ludność z powodu swego wyglądu był nazwany Monasterem oraz pieknie utrzymany ogród, znajdujący się przy nim. Dla sprawowania kultu religijnego postanowili przydzieliź zakonnikom kaplicę cmentarną pod wezwaniem Matki Boskiej 3?.

Żeby nabyć prawnie tę posiadłość należało zgłosić swój zamiar do rady miasta, by otrzymać od niej zgodę; oraz podać go do publicznej wiadomości, by osoby trzecie mogły ewentualnie wnieść swoje zastrzeżenia. Gubernator Hoditz dostosował się do przepisów prawa za pośrednictwem swoich komisarzy, którymi byli: proboszcz z Prudnika i szlachcic Franciszek Lefler 40.

$37 \mathrm{~W}$. S c h we dowitz, Geschichte der Kirchenneuerung in der Neustädter Gegend. Neustadt 1930 s. 40.

38 Bullarium Ordinis Fratrum Minorum Capucinorum. T. IV. Romae 1746 s. 212. (Skrót: Bull. Cap.).

${ }^{39}$ J. C h r z ą s z c z, dz. cyt., s. 200.

$40 \mathrm{~A}$. C., t. III. $1654 \mathrm{nr} 45$, s. $259 \mathrm{n}$. 
Do rady miejskiej zgłosili się zainteresowani. Nieliczni katolicy wyrazili zgodę na przyjęcie do miasta kapucynów. Wśród garstki tej byli jednak rzemieślnicy, jak tkacz wełny Jan Salinger, którzy zaprotestowali, obawiając się od kapucynów rzemieślniczej konkurencji.

Co się zaś tyczy protestantów, ci, z Albertem Scheppe i Janem Heisig na czele, byli jednomyślnie przeciwni sprowadzeniu kapucynów i wzniesieniu klasztoru w Prudniku. Odebrano bowiem protestantom w 1629 r. na rzecz katolików kościól parafialny, który otrzymali w 1556 r. od królowej węgierskiej Izabelli, musieli więc odtąd zadowolić się kaplicą cmentarną, którą na początku wojny 30-letniej częściowo sobie powiększyli. W podziemiach tej kaplicy znajdowały się grobowce bogatych protestantów. Obawiano się więc, że i tę kaplicę przyjdzie im utracić na rzecz kapucynów ${ }^{41}$. Ponownie zebrali sie zainteresowani $w$ magistracie dnia 23 maja $1653 \mathrm{r}$. Wspólnie twierdzili, że miasto jest prawie cale protestanckie; w rekach akatolików znajduje się prawo patronatu, którego to prawa absolutnie nie dadza sobie odebrać i publicznie protestują przeciwko zabraniu im kaplicy.

Gdy przeciwnicy skończyli wysuwać swoje zarzuty, zabrał głos proboszcz miasta Prudnika i jako komisarz występujący w imieniu gubernatora, usiłował wykazać bezpodstawność argumentacji mieszczan. Dowodził, że utrzymanie kapucynów opiera się na kweście a nie na dochodach płynących $z$ wyrobów rzemieślniczych. $Z$ zadomowienia kapucynów $\mathrm{w}$ mieście można spodziewać się nawet pożytku i korzyści. Bowiem, gdy do kościoła kapucynów zaczną naplywać liczni wierni nawet $z$ okolicznych miast $i$ wiosek, wówczas można być pewnym, że nastąpi wzrost dochodów handlarzy i rzemieślników oraz innych mieszkańców tego miasta $\mathbf{4 2}$.

Proboszcz Prudnika Grzegorz Hilner argumentował, iż ze wzgledu na to, że kapucyni utrzymują się z jałmużny i po nią to udawać się będą przede wszystkim do katolickiej szlachty - której niemało jest $\mathrm{w}$ okolicy - protestanccy mieszkanicy Prudnika nie potrzebuja obawiać się, że wypadnie im łożyé na wyżywienie zakonników.43

Jednak przemówienie proboszcza nie odniosło właściwego skutku. Protestanci nadal protestowali przeciwko wprowadzeniu kapucynów do miasta. Na skutek ich sprzeciwu magistrat prudnicki, przesłał gubernatorowi dnia 24 maja $1653 \mathrm{r}$. negatywną odpowiedź 44 .

Biskup Liesch w swoim i hrabiego Hoditza imieniu zwrócił się do biskupa wrocławskiego, który $w$ tym czasie przebywal $\mathrm{w}$ Nysie z prośbą o przekazanie kaplicy cmentarnej w Prudniku kopucynom.

41 A. W e $1 \mathrm{t} z$ e 1 , dz. cyt., s. $684 \mathrm{n}$.

42 A. C., t. III. $1654 \mathrm{nr} 46$, s. $260 \mathrm{n}$.

13 A. Weltzel, dz. cyt., s. 685.

44 A. C., t. III. $1654 \mathrm{nr} 46, \mathrm{~s} .261 \mathrm{n}$. 
Biskup wroclawski Karol Ferdynand wydał w Nysie dnia 2 czerwca 1653 r. pismo, w którym ogłasza zamiar wprowadzenia kapucynow do Prudnika. Dnia 8 czerwca pismo to zostało odczytane $z$ ambony, a następnie przybite do drzwi kościoła parafialnego w Prudniku 45 .

Treść pisma była następująca: Biskup wrocławski podał, że biskup Liesch i hr. Hoditz zamienzali sprowadzić na Sląsk do miasta Prudnika zakon kapucynów i umieścić ich w domu zwanym Monaster, jak również przekazać im kaplicę cmentarną pod wezwaniem Najświętszej Maryi Panny. Prosili więc go, by tę prośbę ich zatwierdzil władzą książęcą i biskupią. Jednak kierując się wymogami prawa, by nie stała się komukolwiek krzywda wydal patent $z$ mocą generalnego pozwu. Dokument ten należalo odczytać $z$ ambony, następnie przybić do drzwi kościoła parafialnego, a bezpośrednio zainteresowanych osobiście powiadomić. Wszystkich więc, którzy sądzili, że mają jakieś prawa do tych nieruchomości, lub jakieś inne pretense, pozwano ich do ostobistego stawienia się przed sąd książęcy w Nysie, w cliągu 30 dni od ogłoszenia patentu. Pozew wydano w tym celu, by rozstrzygnąc pewne zarzuty prawne i sądowe; których nie powinno się uprzedzać. W razie nie stawienia się stron miano uznać je za uporne i przystąpić bez nich do załatwienia sprawy.

Ponieważ biskup wrocławski skierowal sprzeciw protestantów na drogę sądową, obie strony przygotowały się do rozprawy. Biskup Liesch badał pochodzenie kaplicy i prawo patronatu jakie posiadała rada miejska ${ }^{46}$.

Zachowały się bowiem ważne dokumenty dotyczące tej sprawy. Pierwszy - królowej węgierskiej Izabeli, regentki księstwa opolsko-raciborskiego, sporządzony we Lwowie 25 lipca 1556 r. Drugi dokument $\mathrm{z}$ tego okresu, biskupa ołomunckiego, do którego jurysdykcji wówczas Prudnik należał.

Geneza pierwszego dokumentu jest następująca. Królowa Izabela (Jagiellonka), siostra króla polskiego, była małżonką króla węgierskiego Jan Zapolyi. Gdy król Jan zmarł, pozostawił swego następcę małoletniego syna Jana II Zygmunta. Rządy na Węgrzech objąl jednak król Ferdynand, dając księciu Janowi II Zygmuntowi, jako wynagrodzenie za utracony tron węgierski, rozmaite posiadłości. Wśród nich w zastaw dał księstwo opolskie-raciborskie. Królowa Izabela w zastępstwie małoletniego syna została regentką tych księstw, mając do pomocy dwóch komisarzy.

Ferdynand mylnie ocenił królową Izabelę, która jakkolwiek oficjalnie pozostała katoliczką, to jednak w księstwie opolsko-raci-

45 A. W e 1 t z e l, dz. cyt., s. 683 n. Por. Bull. Cap. T. IV. s. 213.

46 A. C., t. III. $1654 \mathrm{nr} 43$, s. 256. 
borskim, a więc i w Prudniku, faktycznie popierała religię protes` tancką. 47

Kiedy zmarł ostatni katolicki proboszcz Prudnika - Marcin Gremell w 1552 r., wówczas królowa Izabela zwróciła się nie do biskupa olomunieckiego, do którego diecezji należał Prudnik, lecz do biskupa wrocławskiego - Baltazara. Jemu to zaprezentowała Samuela Neugebauera na proboszcza. Biskup zatwiendził go wystawiając dokument w Nysie dnia 25 listopada 1552 r. Przekazał mu calą opiekę cluszpasterską i wszystkie parafialne dochody. Postawił jednak warunki, by proboszcz nie naruszał jego praw i praw innych (tzn. biskupa ołomunieckiego) i że ważnie będzie urzędować tak długo, jak długo będzie trwać w posłuszeństwie świętemu Kościołowi katolickiemu i biskupowi.

W tych ciężkich dla religii katolickiej czasach, mogli biskupi ołamunieccy przekazać jednorazowo jurysdykcję nad miastem Prudnikiem biskupowi wroclawskiemu ${ }^{48}$.

W rzeczywistości na podstawie wszystkich późniejszych danych, ostatnim proboszczem katolickim był Marcin Gremell, a Samuel Neugebauer, zaprezentowany przez królową Izabelę, pierwszym luterańskim proboszczem. Pelnil on jednak krótko swój urząd. Złcżył niebawem rezygnację na ręce królowej Izabeli, która wówczas przekazała prawo patronatu radzie miasta Prudnika dokumentem $z$ dnia 25 lipca 1356 r. we Lwowie 43.

W dokumencie przekazującym prawo patronatu radzie miejskiej znajdowal się jeszcze akt darowizny części pola, należącego do dawnego zamku, na grzebanie zmarłych chrześcijan. 50

$Z$ prawa patronatu skorzystano natychmiast, natomiast $z$ otrzymanego kawałka pola nie spieszono się zrobić cmentarza. Dopiero, gdy wybuchła zaraza i zwłok nie można było chować na cmentarzu kościelnym i na placu dookoła kościoła parafialnego, wówczas cała gmina prudnicka zwróciła się do biskupa ołomunieckiego Marka i przedstawiła mu, że do grzebania ciał zmarłych na zarazę musieli używać placu szpitalnego, ponieważ dotychczasowa kaplica Matki Boskiej, stojąca pomiędzy karczmami była zupelnie zniszczona. Mieszczanie chcieli nabyć znaczny ogród przed murami miasta, a między tym ogrodem i placem grzebalnym w zastępstwie starej kaplicy - wybudować nową 51.

Dopiero więc w dziesięć lat później wykorzystano w pełni daro-

47 A. C., t. III. $1654 \mathrm{nr} 40$, s. $251 \mathrm{n}$. Zob. W. F e l c z a k, Historia Węgier. Wroclaw 1966 s. 120 i 122. Por. J. Ch r zą s z c z, dz. cyt., s. $87 \mathrm{n}$.

48 J. Chrzą s z z, dz. cyt., s. 88.

49 Tamże.

so A. C., t. III. $1654 \mathrm{nr} 40$, s. 252 n.

51 J. C hrzą s c z, dz. cyt., s. 98. 
wiznę królowej Izabeli. Dokonano tego dla dobra katolików oraz zgodnie z prawem Kościoła rzymskiego 52.

Biskup olomuniecki dnia 16 maja 1563 roku wyraził zgodę na zalożenie nowego cmentarza i przeniesienie kaplicy $w$ inne miejsce, by była pośrodku nowego cmentarza. Biskup postawil warunki, żeby konsekracja tak nowej kaplicy Matki Boskiej, jak i cmentarza odbyła się według rytu św. Kościoła oraz by odbyły się kościelne ceremonie i poświęcenia. ${ }^{53}$

Swiadectwo to było ostatnim śladem istnienia katolicyzmu. Kaplicy cmentarnej $\mathrm{w}$ następnych latach nie używano do katolickich oirzędów. Całe miasto przeszło na protestantyzm, a rada miasta aż do 1629 roku sprawowała jurysdykcję w rzeczach kościelnych.

W 1629 roku biskup z Ołomunca zrzekł się swoich praw do Prudnika na rzecz biskupa wroclawskiego Karola Ferdynanda. W ten sposób część Górnego Sląska przeszła pod rządy biskupów wrocławskich. Po wieloletniej przerwie biskup wroclawski dnia 2 czerwca 1629 r. mianowal pierwszego proboszcza katolickiego w Prudniku Baltazara Kellera 54.

Analizując wyżej wspomniane dokumenty biskup Liesch stwierdzil, że w dokumencie królowej Izabeli jest mowa o prawie patronatu, które otrzymał magistrat prudnicki, a dotyczy ono tylko kościoła parafialnego. Parafia prudnicka otrzymała również od królowej kawałek pola na plac do założenia cmentarza. Jednak w tym dokumencie nie ma najmniejszej wzmianki o kaplicy Matki Boskiej, która stała się przedmiotem sporu.

Z pisma biskupa z Ołomuńca wynika, że dał on pozwolenie na przeniesienie na nowy cmentarz i powiększenie kaplicy Matki Eoskiej aby służyła jako kaplica cmentarna. Natomiast w dokumencie tym nie ma nic o prawie fundacji, erekcji czy posiadania tej kaplicy.

Fo zapoznaniu się $z$ dwoma wyżej wspomnianymi dokumentami oraz $z$ kodeksami fundacyjnymi biskup nie znalazł niczego, co mogloby komukolwiek stwarzać podstawy do zgloszenia swych pretensji, czy to na zasadzie pochodzenia tej kaplicy, czy też na podsawie nabytych praw ${ }^{55}$.

Dopiero teraz biskup Liesch zdecydował się na zakup domu i ogrodu jako parceli budowlanej pod przyszly klasztor. Parcela ta i dom znajdowały się $w$ rękach protestantów. Wiadome mu było, że protestanci nie chca zgodzić się ma to, by w tym miejscu stanąl klasztor. Obawiał się przeto odmowy sprzedaży danej parceli. Dlatego więc zwrócił się do hrabiego Hoditza z prośbą o pomoc.

52 A. C., t. III. $1654 \mathrm{nr} \mathrm{41,} \mathrm{s.} 253$.

33 Tamże s. 253 n. Por. J. C h r z ą s z c z, dz. cyt., s. 98.

54 J. Chrzasz cz, dz. cyt., s. 99 i s. 177 .

55 A. C., t.III. $1654 \mathrm{nr} 43$, s. 256.

14 - Prawo Kanoniczne Nr 3-4/75 
Gubernator, jako gorliwy katolik projekt działania podany przez biskupa Liescha nie tylko zaaprobowal, ale jeszcze obiecał sprawe posuwać naprzód w miarę swojej władzy wypływającej $z$ urzędu i swoich możliwości 56. Biskup Liesch powierzył mu wówczas dokonanie transakcji kupna posiadłości od spadkobierców Łukasza Sauera. Gubernator natychmiast podjął pertraktacje $\mathrm{z}$ właścicielami, doszedł z nimi do porozumienia i zawarł umowę. Żeby umowa miala moc prawną, potrzeba było zgody rady miasta Prudnika. Członkowie rady udzielili gubernatorowi pozwolenia nabycia nowej posiadłości ${ }^{57}$.

Biskup Liesch dał pieniądze gubernatorowi na zakupienie domu i ogrodu ${ }^{8}$. Sam akt kupna i sprzedaży odbył się w sposób zgodny z prawem. Kontrakt dokonano i dokument sporządzono dnia 13 lipca 1653 r. Za dom i ogród zapłacono 500 talarów śląskich $w$ gotówce pani Susannie Kuntze $z$ domu Sauer, dziedziczce tej posiadłości. Obecny był przy tym jej mąż - Jan Kuntze i opiekun - Jeremiasz Habric. Jan Kuntze zrzek1 się całkowicie wszelkich praw do tej posiadłości. On też był autorem dokumentu kupna i sprzedaży 59 .

Protestanci złożyli w Nysie pismo protestacyjne skierowane do biskupa wrocławskiego, a zarazem księcia i władcy Prudnika - Karola Ferdynanda. Pismo to było następującej treści: Protestnci przypomnieli, że dnia 23 maja $1653 \mathrm{r}$. proboszcz Prudnika w imieniu gubernatora Hoditza przekazał im do wiadomości, że zamierza osiedlić w Prudniku kapucynów i przekazać im kaplicę cmentarną oraz kupić dla nich parcelę od dziedziców Eukasza Sauera. Protestanci zaś mieli postarać się od wladzy kościelnej o inny kościół $\mathrm{w}$ księstwie. Temu zamiarowi gubernatora sprzeciwili się.

Twierdzili, że nikomu bez powodu nie zabraniali, aby w Prudniku nabyl posiadłość ziemską. Miasto posiadało jednak prawnie nabyte przywileje, które dotąd zawsze były zachowywane. Jeden $z$ nich brzmi następująco: „Jeśli jakiś szlachcić w tym mieście, albo we wioskach do tego miasta należących, chciałby zamieszlkać, czyli w nich upatrzoną posiadłość ziemską kupić, aby mogło to zaistnieć,

\footnotetext{
${ }^{56}$ A. C., t. III. $1654 \mathrm{nr} 42$, s. 255.

57 A. C., t. III. $1654 \mathrm{nr} 43$, s. 256.

58 J. Chrząs z c z, dz. cyt., s. 200. Por. Almanach sämtliche Kloster. Breslau 1845 s. $486 \mathrm{n}$.

Autor Almanachu nazywa hrabiego Hoditza fundatorem, dlatego że on dokonał kupna tej parceli i domu. Pieniądze jednak dał na to biskup Liesch i dlatego on jest faktycznym fundatorem.

59 A. C., t. III. $1654 \mathrm{nr} \mathrm{43,} \mathrm{s.} 257$.

$\mathrm{Z}$ dokumentu tego dowiadujemy się o osobie hrabiego Hoditza; jest w nim bowiem wymieniony pełny jego tytuł i wyliczone pasiadłości. Hrabia był doradca cesarza, arcyksięcia Austrii Leopolda Wilhelma, Karola Ferdynanda księcia polskiego i szwedzkiego, a także był gubernatorem księstwa opolsko-raciborskiego. Hr. Hoditz był także wlaścicielem licznych posiadłości.
} 
wpierw musi mieć ta osoba papiery opatrzone pieczęcią magistratu, bez których nikomu do miasta, czy też do niego należących wiosek wprowadzić się nie wolno".

Co się tyczy kupna domu i ogrodu przez gubernatora, stwierdzili, iż nie złożył on odpowiednich papierów opatrzonych pieczęcią, a zatem kupno jego jako niezgodne z przywilejami nie ma mocy prawnej. .0 $^{6}$

Gubernator chciał przekazać dom i ogród zakonnikom żebrzącym, którzy nie posiadali prawa własności $i$ byli równiez wolni od danin, opłat i podatków. Zatem cały ciężar podatkowy z dornu i ogrodu, należny księciu jako część podatku z miasta Prudnika, przejdzie na mieszczan, ponieważ wszystkie podatki i daniny musza płacić wspólnie z całego miasta. Prudnik w czasie wojny trzydziestoletniej, nadzwyczajnymi podatkami byl obkładany, $z$ tego powodu znacznie zubożał. Przed 26 laty był duży pożar, spaliło się wówczas większość domostw i nie zdołano ich odbudować. Dlatego przełożenie na mieszczan podatku ze wspomnianej posiadłości ogrodu i domu, przeznaczonego na zakonną fundację, wydawało się dla mieszczan ciężarem nie do zniesienia. ${ }^{61}$

W okolicy Prudnika znajdowały się klasztory. Jeśliby ktoś życzył sobie w nich się modlić, łatwo mógł się do nich udać, gdyż znajdowały się $w$ niewielkiej odległości od Prudnika. Prócz tego miasto obowiązane było rocznie płacić na rzecz klasztoru w Głogówku 156 talarów. Magistrat też musiał udzielać srodków do życia wdowom i sierotom, z których większa część miała ledwie kawałek chleba, by zachować życie.

Argumentowano, że gdy stanie klasztor i kościół na wspomnianej parceli, obiekt ten będzie stwarzal wielkie niebezpieczeństwo dla miasta na wypadek wojny. czy nagłego podejścia wroga.

Protestanci twierdzili, że wprowadzenie kapucynów naruszy prawo własności. Mieszczanie posiadali do kaplicy i cmentarza nabyte prawa. W żaden sposób nie chcieli pozwolić, by tej kaplicy i cmentarza pozbawiono ich, ani nie chcieli się zrzec nabytych praw.

Poza miastem, dla grzebania zmarłych już od niepamiętnych czasów, miasto posiadało cmentarz razem z kaplicą, która ponad 90 lat na nim stała. Do poszerzenia cmentarza mieszczanie kupili ogrody i w tym miejscu wspólnym wysiłkiem wybudowali kaplicę.

Do mieszczan należało prawo patronatu $i$ to $z$ potrójnego tytułu: 1) przez niepamiętne przedawnienie, do którego wystarczało 40 lat; 2) przez wybudowanie i kupno dokonane przez przodków, po których kościól i cmentarz odziedziczyli; 3) przez ogloszenie od 1597 ro-

60 A. C., t. III. nr 47, s. 264 n.

o1 Tamże s. 265. Straszliwa klęska żywiołowa nawiedziła Prudnik w 1627 r. Wówczas z maista ocalało tylko cztery domy. Por. W. G r a b s ki, 300 miast wrócito do Polski. Warszawa 1960 s. 365. 
ku kaplicy cmentarnej kościołem filialnym kościoła parafialnego. $\mathrm{W}$ takim wypadku, według prawa, należało sądzić, że kaplica cmentarna we wszystkim podlega kościołowi parafialnemu jako macierzystemu (quod naturam sui principalis sequitur aestimata est). Tak znajduje się nawet $\mathrm{w}$ cesarskim urbarium. ${ }^{62}$ Mieszczanie kaplicy zawsze używali w spokoju i korzystali z tego prawa.

Tak, jak przodkowie, również współcześni obywatele Prudnika proboszcza prezentowali. W wyniku czego otrzymywal on od mieszczan zapłate za kazania i inne ceremonie. Co więcej, przed niewieloma laty gubernator prowincji Fryderyk hrabia z Opersdorf prawo patronatu i wszystko, co się z nim wiąże, poparł i zabezpieczyl z ramienia Cesarskiego Majestatu.

W 1627 roku kościól parafialny spalił się. Wówczas filialna kaplica, na którą rozciągalo się prawo parafialne, musiała protestantom zastępować kościól macierzysty i stan ten nie zmienił się.

Gdyby jednak postanowienie sprowadzenia kapucynów było nieodwołalne, protestanccy mieszczanie usilnie prosili tak księcia biskupa wrocławskiego, jak również biskupa Liescha i gubernatora Hoditza, żeby zechcieli inny plac obrać pod budowę (a parceli wolnych bylo dużo) i tam wystawić klasztor i kościół kapucynom, a im, by nie odbierali kaplicy cmentarnej.

Pismo zakończono uroczystym protestem przeciwko wprowadzeniu do miasta Prudnika tak kapucynów, jak i jakichkolwiek innych zakonników. ${ }^{63}$

Rozprawa sądowa odbyła się w Nysie dnia 18 lipca 1653 r. Sędzią był sam książę biskup wrocławski Karol Ferdynand - jako sędzia zwyczajny. W celu podniesienia uroczystego charakteru rozprawy, na sali byli obecni tacy dostojnicy jak: Gotthard Franciszek Schaffgotsch - wrocławskj kantor, Jan Franciszek Wilczek - kanclerz wrocławski, archidiakon opolski, dziekan raciborski, Adam Heltzelio - kanonik i proboszcz Nysy i inni liczni świadkowie. Do sądu biskupiego stawili się szlachcice: Jan Fryderyk Grün i Jeremiasz Szubert - obaj senatorzy miasta Prudnika. Byli oni przedstawicielami katolickich obywateli. Ze strony mieszczan - luteran przybyli również przedstawiciele w osobach Daniela Alberta Scheppe i Jana Heisigiusa. Udzielono im głosu, by mogli się wypowiedzieć i podać prze-

62 Urbarium $=$,Spis powinności gruntowych obowiązujących poddanych wobec pana; powinnośc zapisana w takim spisie". Polska Akademia Nauk, Stownik Języka Polskiego. T. IX. Warszawa 1967 s. 646.

${ }_{03}$ A. C., t. III. $1654 \mathrm{nr} 47$, s. $265 \mathrm{n}$.

Należy przypuszczać, że dokument ten został sporządzony między $8 \mathrm{czerw}-$ ca a 13 lipca 1653 r. Data 8 czerwea jest wymieniona w dokumencie. W piśmie tym protestanci zarzucają gubernatorowi nieprawny sposób nabycia własności. Natomiast w dniu 13 lipca gubernator posiadał już wszystkie dokumenty potrzebne do zgodnego z prawem - kupna domu i ogrodu. 
pisy prawne na poparcie swoich argumentów. Tych zaś, którzy otrzymali pozew, mieli pretensje, a nie stawili się - uznano za upornych.

Reprezentanci katolików życzyli sobie, by ich nabyte prawa pozostały nienaruszone, nie tylko odnośnie prawa patronatu i prezentowania do kościoła parafialnego, lecz także wszystkie i poszczególne przywileje miasta Prudnika, zarezerwowane dla całego okręgu. Co się zaś tyczyło zamierzonej fundacji kapucynow w Prudniku - na założenie jej zgadzali się.

Przedstawiciele luteran zwalczali projekt fundacji kapucynów. Szczególnie odmawiali odstąpienia kaplicy. Argumentowali w sposób podany $\mathrm{w}$ piśmie protestacyjnym.

Książę biskup - po wysłuchaniu stron i zaznajomieniu się $\mathrm{z}$ dokumentami pochodzącymi od królowej Izabeli, jak też z urbarium i dołączonymi pismami spadkowymi - stwierdził, że w dokumentach nie ma wzmianki o jakiejkolwiek kaplicy filialnej, przyłączonej do kościoła parafialnego. Dlatego też nie można wyciągać wniosku, ze istnieje między kościolem parafialnym w Prudniku a kaplicą cmentarną jakaś unia lub inkorporacja. Argumenty protestantów zostały uznane jako słabe i niewystarczające.

Biskup jako sędzia zwyczajny zawyrokował, że zakonników kapucynów zakonu św. Franciszka na stałe należy osiedlić i wprowadzić w posiadanie wspomnianej kaplicy, gdyz jest to miejsce dla nich odpowiednie. Kaplicę mają używać i konserwować tak współcześni kapucyni, jak też ich następcy, $\mathrm{z}$ zachowaniem nienaruszonych praw i wszystkich przywilejów miasta Prudnika i całego okręgu.

Sędzia również nakazał sporządzić dokumenty erekcji i fundacji wediug obowiązującej formy prawnej.

Wyrok ten strona sprzeciwiająca się przyjęła i poddała się mu, bez zarezerwowania sobie jakiejś pretensji i bez jakiegokolwiek oznaczenia czasu na apelację.

Sporządzony wyrok tej rozprawy biskup wrocławski wystawil w Nysie dnia 18 lipca 1653 roku. ${ }^{64}$

Protestanci mieli jeszcze nadzieję, że uda im się przeszkodzić wprowadzeniu kapucynów do Prudnika. Wysłali w tej sprawie pismo protestacyjne do cesarza. Ale i tam nic nie osiągnęli.65

\section{Grupa misjonarzy kapucyńskich bada możliwości osiedlenia się w Prudniku i Nysie}

Dnia 1 września 1653 r. zwrócił się biskup wrocławski Karol Ferdynand do generała zakonu kapucynów - ojca Fortunata z Ka-

${ }^{64}$ Bull. Cap. T. IV, s. 213 n. Por. A. C., t. III. 1654 nr 48, s. 267-270.

85 A. W e 1 t $z$ e 1 , dz. cyt., s. 205. 
doru z prośbą by zechcial członków swojego zakonu asiedlić na nowym terenie, mianowicie na Sląsku.

Dnia 14 października tegoż roku biskup pomocniczy Liesch zwrócił się do prowincjała kapucyńskiej prowincji austriacko-czeskiej o. Samuela $z$ Pilsenburga $z$ prośbą, aby posłał dwóch zakonnych księży, którzy by obejrzeli miejsce i wskazali według jakiego stylu powinna być budowla.

Generał zakonu dnia 10 stycznia 1654 r. dał odpowiedź biskupowi wrocławskiemu. W piśmie swym wyraził zgodę na założenie na Sląsku w mieście Prudniku nowego klasztoru kapucyńskiego.

Biskup Liesch zawiadomił dnia 18 stycznia 1654 roku prowincjała kapucynów w Brnie, że biskup wrocławski Karol Ferdynand, który wyjechał do Polski, przekazał mu funkcję wprowadzenia kapucynów do Prudnika. W piśmie tym biskup Liesch jeszcze raz ponawia prośbę, by prowincjał zechciał przyspieszyć wysłanie księży zakonnych.

Biskup Karol Ferdynand z Warszawy, do której ze Sląska przybył, osabiście ponowił prośbę o przyspieszenie przysłania kapucynów na ziemie śląskie. Pismo swoje skierował wprost do generała zakonu. ${ }^{66}$

Biskup wrocławski Karol Ferdynand, biskup pomocniczy Baltazar Liesch, Jerzy Maksymilian hrabia Hoditz - gubernator ksiestwa opolsko-raciborskiego, jak też hrabia Franciszek z Fernemond - gubernator księstwa glogowskiego zamiar sprowadzenia kapucynów na Sląsk przedstawili również cesarzowi. Cesarz dnia 5 maja wysłał pismo do prowincjała popierające prośby panów śląsikich. 67

W maju 1654 r. w klasztorze kapucyńskim w Linzu postanowiono wysłać sześciu misjonarzy na Sląsk. Byli to: o. Jowita z Döle w hrabstwie burgundzkim, który przed dziesięcioma laty byl gwardianem $w$ Ołomuńcu, ${ }^{68}$ o. Elzeary ślązak, o. Elizeusz ślązak, o. Ezechiel z Bambergen, Francuz, o. Hilary z Weissenhorn, szwab, o. Ryszard z Lorens, Francuz.

Przełożonym dla tej grupy zostal mianowany przez definitorium o. Jowita, który od cesarza otrzymał listy uwierzytelniające. ${ }^{69}$

Ojcowie misjonarze byli wybrani z różnych klasztorów prowincji. Wspólnie zebrali się w Ołomuńcu. Tam otrzymali błogosławieństwo swoich przełożonych i udali się w drogę na Sląsk. ${ }^{70}$

Władze zakonne kapucyńskie prowincji austriacko-czeskiej wysyłając grupę misjanarzy na Sląsik miały przede wszystkim na uwa-

${ }_{66}$ A. W e 1 t z e l, dz. cyt., s. 684 .

67 A. C., t. III. $1654 \mathrm{nr} 49$,s. 270.

68 Według prawa zakonnego kapucyni nie używali nazwiska, tylko przy imieniu zakonnym (nie chrzestnym) podawali miejscowość lub kraj skąd pochodzili. Np. o. Jowita pochodzil z Döle w hrabstwie burgundzkim. W kronice prowincji prócz jednego, wyżej wymienionego miejsca, imie jego wielokrotnie jest notowane: o. Jowita z Burgundii.

${ }_{69}$ A. C., t. III. $1654 \mathrm{nr} 49$, s. 270. Zob. A. Welt z el, dz. cyt., s. $685 \mathrm{n}$.

70 A. C., t. III. $1654 \mathrm{nr} 49$, s. 271. 
dze dwie miejscowości: Wrocław i Zieloną Górę. W obydwu tych miejscowościach już pracowali dawniej kapucyni, a we Wrocławiu mieli nawet plac, materiały budowlane i trochę pieniędzy na budowę klasztoru. Natomiast w Zielonej Górze nie tylko istniała tradycja kapucyńskiej pracy misyjnej, ale nawet jeden $\mathrm{z}$ nich piastowal urząd proboszcza. Dlatego prośbę o kapucynów Jana Franciszka, wolnego barona $z$ Fernemond, gubernatora księstwa glogowskiego przyjęto $\mathrm{z}$ zadowoleniem. O. Jowita otrzymal listy polecające do gubernatora i nakaz, by jak najprędzej udał się do Wrocławia i Głogowa $\mathrm{w}$ celu zbadania na miejscu warunków i możliwości założenia klasztorów we Wrocławiu i księstwie glogowskim.

Definitorium kapucyńskie prowincji austriacko-czeskiej nic nie wiedziało o przygotowaniach i planach fundacyjnych wrocławskiego biskupa pomocniczego Baltazara Liescha. Ten zaś po naradzie $z$ gubernatorem księstwa opolsko-raciborskiegc hr. Hoditzem i gubernatorem księstwa glogowskiego Franciszkiem Fernemond ustalił, że pierwszy klasztor kapucyński ufundowany zostanie w Prudniku. Gubernator Fernemond nie zrzekł się przez to chęci osiedlenia kapucynów w księstwie głogowskim, ale nie mając gotowych funduszy musial decyzję wyboru pierwszej placówki oddać biskupowi Lieschowi.

Grupa misjonarzy kapucyńskich pod przewodnictwem o. Jowity miała za cel dojść do Wrocławia i księstwa głogowskiego. Jednak musieli wpierw stawić się przed władzą duchowną diecezji wrocławskiej, w celu otrzymania jurysdykcji i listów polecających. Biskupi wrocławscy mieli wówczas swoją siedzibę w Nysie. Dlatego kapucyńscy misjonarze musieli wpierw przybyć do tego miasta.

Dnia 6 lipca $1654 \mathrm{r}$. dotarli oni do Nysy. W mieście tym miał również swą stałą siedzibę biskup pomocniczy Liesch, który przyjąl serdecznie kapucynów w swojej biskupiej rezydencji.

$\mathrm{Na}$ drugi dzien, biskup Liesch osobiście towarzyszył kapucynom w zwiedzaniu miasta i jego zabytków. Pokazywał im różne domy pytając, czy ojcowie nie uznają za stosowne w przyszłości, w którymś $z$ nich zamieszkać na stałe. ${ }^{71}$ Ponieważ biskup Liesch mial zamiar osiedlić kapucynów nie tylko w Prudniku, ale również w Nysie, dlatego usiłowal przekonać zakonników, by zechcieli powziąść zobowiązanie założenia tu klasztoru. Ojcowie byli zdziwieni planami biskupa Liescha, nie mając jednak w tej sprawie żadnych pelnomocnictw od swych wyższych przełożonych, nie mogli zgodzić się na nową propozycję.

Na drugi dzień, zabrał biskup ojców ze sobą na zwiedzanie przedmieść Nysy.

Za miastem znajdowało się wzgórze. Leżało ono za rzeką Nysą przy moście wiodącym do drogi wrocławskiej. Na wzgórzu tym stal

71 Tamże s. $271 \mathrm{n}$. 
szpital dla biednych kobiet. Za budynkiem szpitalnym był kościól pod wezwaniem świętych Wawrzyńca i Łazarza. Wzgórze było otoczone ogrodami oraz zieleńcami. Było to miejsce zaciszne, oddalone od zgiełku miasta.

Misjonarze, gdy oglądnęli kościól i dom szpitalny, zwiedzili ogrody i zieleńce, uznali, że jest to miejsce jak najbardziej stosowne do założenia klasztoru kapucyńskiego. Opinia ta ucieszyła biskupa. Kapucyni byli świadkami jak biskup Liesch zaraz rozpoczął pertraktacje $z$ właścicielami w sprawie sprzedaży tego miejsca. Dowiadywal się, w jaki sposób będzie można miejsce to przygotować na przyszły konwent kapucynów. ${ }^{72}$ Powiadomiony przez biskupa Liescha gubernator Hoditz przyjechał do Nysy, by przywitać tak długo oczekiwanych gości i zaprosil ich do Prudnika.

Ojcowie kapucyni $\mathrm{z}$ udaniem się do Prudnika nie zwlekali. Dzień opuszczenia Nysy został wyznaczony na 11 lipca, w sobotę. Rano, wyruszyło sześciu kapucynów piechotą i boso z Nysy do Prudnika. Do towarzystwa mieli konnych i pieszych przewodników. ${ }^{73}$

Wkrótce za ojcami wyjechali z Nysy biskup Liesch i hrabia Hoditz w powozach zaprzężonych każdy w sześć k.oni. Do Prudinika wysłano gońca, który powiadomił mieszlkańców o zbliżaniu się kapucynów do miasta. Przed Prudnikiom dostojnicy w powozach przyłączyli się do kapucynów. Misjonarze więc weszli do miasta w towarzystwie orszaku biskupa Liescha i gubernatora księstwa opolskoraciborskiego - hrabiego Hoditza. Orszak ten powiększyło piętnastu konnych rycerzy, dołączyli się także katoliccy obywatele miasta. ${ }^{74}$

Widok kapucynów wzbudził w mieszkańcach różne uczucia. Katolicy cieszyli się z przybycia zakonników.

Luteranie natomiast byli wyraźnie niezadowoleni. Szemrali i wygłaszali uwagi pod adresem kapucynów. Wyśmiewali ich powagę, chodzenie $z$ bosymi nogami, dziwaczny, surowy i prosty strój, a zwłaszcza przedmiotem drwin był piramidalny kaptur kapucyński. Winili biskupa Liescha za przyprowadzenie do Prudnika misjonarzy katolickich. Przewidywali, że przy ich pomocy biskup zechce cala okolicę nawrócić na wiarę katolicką.

Tymezasem pochód dotarł do budynku gubernatora Hoditza. Przygotowano tu przyjęcie dla zmęczonych marszem kapucynów i dla innych dostojnych gości. W celu uświetnienia uroczystego przyjęcia hrabia Hoditz przyprowadził swoich śpiewaków. $Z$ gości, prócz biskupa Liescha, byli przedstawiciele magistratu i senatu miasta Prudnika oraz rodzina hrabiego Hoditza. Deputowani komisarze magistratu $\mathrm{z}$ radością przywitali misjonarzy $\mathrm{w}$ imieniu wszystkich mieszkańców Prudnika. Jeden $\mathrm{z}$ ojców kapucynów w zwięzłych słowach

72 A. C., t. III. $1654 \mathrm{nr} 50$, s. 272.

73 Tamże s. $272 \mathrm{n}$.

74 A. C., t. III. 1654 nr 51, s. 273. Por. A. C., t. III. 1654 nr 52, s. 275 n. 
wyraził swoje podziękowanie. Szczególnie dziękowal za nadzwyczaj humanitarny sposób zachowania się wobec nich, ubogich i skromnych zakonników. Ze swej strony mówca obiecał swoje i swoich braci zasìugi duchowne ofiarować najwyższemu Bogu na pomyślność, powodzenie i bezpieczeństwo miasta i całej jego społeczności.75

W dniu 12 lipca przypadała VI niedziela po zesłaniu Ducha św. Ksiądz proboszcz chciał, by wszyscy jego parafianie mogli zobaczyć zakonników przy ołtarzu, dlatego wyznaczył im pojedyńczo czas na odprawianie mszy św. przy głównym ołtarzu.

W całkowitej tajemnicy przed misjonarzami trzymano to wszystko, co dotąd dla ich dobra wystarano się i osiagnięto w Prudniku za sprawą księcia biskupa wrocławskiego.

Po południu biskup Liesch, gubernator Hoditz, proboszcz Prudnika i starsi miasta poszli wraz z misjonarzami do posiadłości, która kupił juz hrabia Hoditz. Ojcowie miejsce to i jego otoczenie oglądali $\mathrm{z}$ zadowoleniem. Wszystko wyglądało tak, jak.w typowych konwentach kapucyńskich. Bowiem kaplica uboga, ale w sposób artystyczny ozdobiona. Dom przedstawiał forme $w$ kwadrat zbudowanego obiektu. Ogród, pelen drzew i kwiatów, podobny był bardzo do ogrodów zakonnych kapucynów. Wszystko tu doskonale nadawało się do założenia klasztoru.

Ojcowie nie tylko oglądali i podziwiali, ale natychmiast na miejscu wszystkie warunki i środki utrzymania spisywali.

Teraz dopiero biskup Liesch i hrabia Hoditz opowiedzieli ojcom, jaki jest w obecnej chwili stan faktyczny i prawny tej posiadłości i co już dotąd zostało zrobione dla kapucynów. Na szczegółowych oględzinach i omawianiu spraw zeszedł im czas do późnej nocy. Przed udaniem się na spoczynek ojcowie powiedzieli o swym zamiarze udania się nazajutrz z powrotem do Nysy. Jednak na usilne prośby przedstawicieli magistratu i senatu prudnickiego, misjonarze, choć im było to niedogodne, zgodzili się pozostać jeszcze jeden dzień.

$V_{i}$ dniu 13 lipca pracownicy magistratu i senatu miasta urządzili ojcom specjalne przyjęcie. Wśród rodzinnej atmosfery, serdecznych rozmów, mijały godziny. Ojcowie zetknęli się z ludźmi, którzy darzyli ich oznakami najwyższej przyjaźni.

Dnia 14 lipca kapucyni podziękowali za serdeczne przyjęcie hrabiemu Hoditzowi oraz magistratowi miasta i udali się wraz $z$ biskupem Lieschem $z$ powrotem do Nysy. ${ }^{76}$

Ojciec Jowita z Burgundii, jako przełożony grupy misyjnej, w dniu 15 lipca w Nysie spisał protokół sprawozdawczy ze stanu rzeczy na Sląsku, a w szczególności z miasta Prudnika (czyli Polskiego Nowego Miasta). List przesłal ojcu prowincjałowi Samuelowi z Pilsenburga, do Wiednia. Ważna jest podana przez niego charakte-

75 A. C.,t.III. 1654 nr 51, s. 273 n.

${ }^{78}$ A. C., t. III. $1654 \mathrm{nr} 52$, s. $274 \mathrm{n}$. 
rystyka miejsca pod przyszły klasztor. Miejsce to znajdowało sie obok miasta. Od murów obronnych oddzielone tylko fosą, leżało pomiędzy dwoma miejskimi bramami na wzgórzu. $Z$ jednej tylko strony stało miasto. $Z$ pozostałych trzech stron roztaczała się równina. $\mathrm{W}$ odległości około jednej mili wznosiły się góry. Na placu stała kaplica, która $z$ wyglądu była taka, jakie zwykli wznosić w swoich konwentach kapucyni. Kaplica posiadała chór zdatny i wystarczający. Nieopodal kaplicy stał przyłączony do posiadłości dom, jak najbardziej odpowiedni na klasztor. Budynek ten znajdowal się w oddaleniu od innych domów, przy nim byl plac i spichlerz. Parcela posiadala przyłączone dwa ogrody - warzywny i owocowy. Rozmiary ogrodów w linii prostej 180 kroków długości i 140 kroków szerokości. Ogród był dobrze zagospodarowany, tylko trzeba go było otoczyć murem. Wody było pod dicstatkiem tak dia potrzeb kuchni, jak i ogrodu. Ziemia urodzajna i łatwa do uprawy. W mieście można bylo nabyć wszystko $z$ wyjątkiem wina. Mieszczanie jednak prowadzili stały handel winem $\mathrm{z}$ Węgrami, Austrią i Morawami. Za pośerdnictwem więc njch można było go sprowadzić. Co do zdobycia wosku nie było trudności. Pod względem rozległości miasto nie było duże; zamieszkiwali je natomiast bogaci ludzie. Zaludnienie było gęste. Ludność przeważnie wyznania luterańskiego, wykształcona i kulturalna. Senat miejski był cały katolicki, nawet żywił do kapucynów serdeczne uczucia, przyrzekł na przyszłość swoja pomoc

Brakowało $w$ tym mieście środków do leczenia. Byl jednak aptekarz, chirurdzy $i$ kąpielowi, od których w razie potrzeby można było otrzymać usługę. W wypadku gdyby lekarz okazal się konieczny, można go bylo łatwo przywieźć $z$ innych miast.

Prudnik leżał w pobliżu takich miast jak: Nysa, Jägerndorf (obecnie: Krnov), Opole. $W$ okolicy zamieszkiwali jedni z najbogatszych ludzi prowincji tacy, jak hrabia z Hoditz, hr. z Herberstein, hr. z Mottingen i inni.

W dalszym ciągu swego listu prosil o. Jowita prowincjała, by zechoiał coś napisać do biskupa Liescha, który pragnie, by jak najprędzej rozpoczęła się budowa konwentu w Prudniku. Wprawdzie o. Jowita ze swej strony wyrazil pewne nadzieje, jednak biskup chciałby mieć pewność, której nie mógł mu o. Jowita dać, gdyż nie otrzymal $\mathrm{w}$ tej sprawie pełnomocnictwa od swoich wyższych przelożonych. ${ }^{77}$

$\mathrm{Z}$ relacji o. Jowity mógł prowincjał wyciągnąc dodatnie wnioski. Pomimo, że katolicy w Prudniku stanowili mniejszość religijną, to jednak ogół warunków stwarzał realne możliwości założenia nowego klasztoru.

77 A. C., t. III. 1654 nr 52, s. 275-277. 
IV. Kapucyńscy misjonarze badaja możliwości osiedlenia się we Wroclawiu, Zielonej Górze í Slawie

Ojcowie kapucyni w Nysie przygotowywali sie do ostatecznego wykonania swojej misji, dla której zostali wysłani na Sląsk.

Biskup Liesch od o. Jowity dowiedział się, jaki jest program grupy misyjnej, której przewodniczył. Misja została zorganjzowana na skutek próśb biskupa wrocławskiego i jego biskupa pomocniczego, a szczególnie gubernatora księstwa głogowskiego - Franciszkka Fernemond. $O$. Jowita oświadczył, że misjonarze zostali wyslani na Sląsk w tym celu, by wybadać jakie życzenia i intencje ma hrabia Fernemond, jak również, by stwierdzić, czy na Sląsku da się założyć konwenty. ${ }^{78}$

Po zdaniu relacji przez o. Jowitę biskup Liesch postawił o. Jowicie następujące żądania. Po pierwsze, by on w liście do swoich wyższych przelożonych napisal, że biskup Liesch wyraża gotowość założenia klasztorów w Prudniku i Nysie i by o. Jowita swoją wymową i argumentacją przekonal swoich wyższych przełożonych o potrzebie i przydatności założenia w tych miastach nowych klasztorów kapucyńskich. Po drugie, by o. Jowita dwóch ojców ze swojej grupy zostawil w Nysie, w celu głoszenia kazań w okolicy.

O. Jowita zgodził się na obydwa żądania. W Nysie pozostawił dwóch ojców, mianowicie o. Elizeusza ze Sląska i o. Ezechiela z Bambergen do dyspozycji biskupa Lïescha.

Sam o. Jowita $z$ o. Elzearym ze Sląska, Hilarym $z$ Weissenhorn i Ryszardem z Frankonii przygotował się do podróży do księstwa głogowskiego. Prosił biskupa Liescha o pozwolenie na dalszą wędrówkę po diecezji, o list polecający oraz władzę sprawowania funkcji kapłańskich, żeby na terenie diecezji wrocławskiej, gdziekolwiek się znajdą, mogli spełniać obowiązki należące do misjonarzy, tj. głosić kazania, szafować sakramentami, słuchać spowiedzi, przyjmować wyznania wiary od protestantów, jak również rozgrzeszać od grzechów zarezerwowanych biskupowi.

Sędziwy biskup Baltazar Liesch, dnia 18 lipca 1654 r. zaopatrzył o. Jowite $\mathrm{w}$ odpowiedni dokument $\mathrm{i} \mathrm{z}$ blogosławieństwem wyslał w dalszą drogę po ziemi śląskiej. ${ }^{79}$

Czterej misjonarze kapucyńscy opuścili Nysę i udali się do Wrocławia. Przybyli tam 21 lipca. Biskup Liesch powiadomił ks. dziekana Filipa Jakuba $z$ Gerin, prałata kościoła katedralnego św. Jana Chrzciciela we Wrocławiu, że z Nysy do Wrocławia udali się misjonarze kapucyńscy. Ksiądz dziekan, uradowany przybyciem katolickich pracowników "Winnicy Pańskiej”, nie czekał ich w swej rezydencji, lecz wyszedł im naprzeciw. Radość i serdeczność, jaką okazal

78 A. C., t. III. 1654 nr 53, s. 277 n.

79 Tamże s. $278 \mathrm{n}$. 
witając zakonników, oraz gościnność, którą w jego domu doznali, wprost zaskoczyła ojców. Tak wielka i niezwykła gościnność, jakiej tutaj doznawali, przechodzila wszelkie ich oczekiwania. ${ }^{80}$

Ojciec Jowita miał we Wrocławiu do załatwienia ważne sprawy. Przed dwudziestoma trzema laty byli tutaj kapucyni. Mieli parcele pod budowę klasztoru i zapisane dobra w testamencie przez hrabiego Karola Hannibala z Dohnau. Chodziło o stwierdzenie, jaki jest obecnie stan faktyczny tych spraw.

Prezesem senatu miasta Wrocławia był Ifonorat $z$ Forno, wielki przyjaciel i dobrodziej zakonu kapucynów. Do niego miał więc udać się o. Jowita w celu wyświetlenia spraw, dotyczących legatu zapisanego zakcnowi kapucynów. Po przybyciu do Wrocławia o. Jowita dowiedzial się, że Honorat z Forno zmarł 16 lipca 1654 r. - złożył więc wizytę wdowie po zmarłym dobrodzieju.

Nowym prezesem senatu został Melchior Ferdynand hrabia z Kaschin. O. Jowita pospieszył złożyć mu gratulacje i wyjawił przy tym właściwy cel swego przybycia do Wrocławia. Powiedzial, że przełożeni polecili $\mathrm{mu}$ zrealizowanie legatu nadanego przez hrabiego z Dohnau. Hrabia Hannibal czyniąc zapis na rzecz kapucynów pragnął zapoczątkować budowę przyszłego klasztoru kapucynów we Wrocławiu. O. Jowita poprosił więc prezesa senatu wrocławskiego o pomoc w załatwieniu tej sprawy. Hrabia z Kaschin, po przeczytaniu listów polecających od cesarza, wyraził swą radość, że cesarz popiera misję kapucynów na Ṡląsku. Sam ze swej strony obiecał pomoc w miarę swoich możliwości. Nie mógł jednak o. Jowicie załatwić tych spraw natychmiast, chociaż ten się spieszył, objął bowiem dopiero urząd i nie orientował się jeszcze w sprawach materialnych miasta Wrocławia. Wkrótce jednak dowiedzial się o. Jowita, że pieniądze zapisane legatem są zachowane. Natomiast, co się tyczy spraw nieruchomości, cały senat miasta Wrocławia wyraził wielkie zdziwienie z powodu legatu hrabiego Hannibala z Dohnau odnośnie placu pod budowę przyszłego klasztoru kapucynów i na razie, co do realizacji testamentu $\mathrm{w}$ tym punkcie, nie dał o. Jowicie żadnej odpowiedzi. ${ }^{81}$

Sprawa zrealizowania legatu wymagala jeszcze zgody rodziny zmarłego dobrodzieja. W legacie były bowiem zapisane ogrody i wszystkie budynki hrabiego we Wrocławiu, a także plac pod budowę klasztoru.

80 A. C., t. III. $1654 \mathrm{nr} 54$, s. 280.

81 Senat wyraził zdziwienie, ponieważ, by można było osiedlić się we Wrocławiu potrzeba było otrzymać dokumenty prawne od rady miejskiej. Osiągnięcie praw miejskich na wprowadzenie się do miasta i praw na założeniet klasztoru wymagało wielu zabiegów i pertraktacji. $O$ tym senat miasta Wrocławia nic nie wiedział, gdyż nie miały one miejsca. Wymowne więc bylo zdziwienie senatorów miasta. 
O. Jowita udal się więc do burmistrza miasta Wrocławia Erharda, Ferdynanda hrabiego z Truchses, który zawarł związek małżeński z burgrabianką z Dohnau, dziedziczką zmarłego ofiarodawcy. Odwiedział również staruszkę wdowę po zmarłym Karolu Hannibalu z Dohnau. Złożył jeszcze uszanowanie archidiakonowi Sebastianowi z Rostoku.

Ponieważ jednak o. Jowita spieszył się, by jak najprędzej stawić się u gubernatora Fernemond w Głogowie, dalsze załatwienie spraw związanych z realizacją legatu powierzył więc siostrze Jakubie ksieni klasztoru św. Klary.

Ks. dziekan Filip Jakub z Gerin starał się zatrzymać ojców jeszcze we Wrocławiu. Widząc jednak, że dalsza podróż misjonarzy jest nakazem zakonnego posłuszeństwa - dał wskazówki, jak i czym mają się udać do Glogowa i zaopatrzył ojców we wszystko tak, by im niczeg.o nie brakowało w czasie podróży. Kapucyni podziękowali za gościnę i dnia 25 lipca wyruszyli drogą wodną rzeką Odrą z Wroclawia do Glogowa. ${ }^{82}$

Dria 28 lipca przybyli na miejsce. Od razu udali się do zamku, w którym rezydował gubernator baron Franciszek Fernemond. Ojcowie zostali przyjęci przez gubernatora, jego rodzinę $\mathbf{i}$ domowników. $Z$ powodu jednak braku miejsca $w$ zamku, w którym zamieszkiwal gubernator, nie otrzymali w nim kwatery, lecz wysłano ich do klasztoru Braci Mniejszych Obserwantćw. Tu mieszkali przez szereg dni. W kościele oo. obserwantów obchodzili uroczyście święto zakonne Porciunkuli.83

Zaraz na drugi dzień po przybyciu do Głogowa o. Jowita przedlożył swoje dokumenty gubernatorowi. Były to listy polecające i dokument pozwalający na załoźenie placówek misyjnych na terenie księstwa. O. Jowita udal się również do księdza dziekana głogowskiego Baltazara Magiusa, który byl zarazem komisarzem do spraw duchownych na terenie księstwa głogowskiego.84 $\mathrm{Z}$ nim przeprowadził rozmowy na temat możliwości założenia placówek misyjnych.

Założenie placwki misyjnej w Glogowie nie było odpowiednie z tego powodu, że protestanci otrzymali tu od cesarza przywilej, który przekreślił wszelką nadzieję nawrócenia protestantów na wiarę katolicką.

Jeśli chodzi o założenie w Głogowie klasztoru, nie było żadnych środków materialnych, potrzebnych do wykonania tego zamiaru.

\footnotetext{
82 A. C., t. III. 1654 nr 55 ,s. 280 n. Zob. Tamże s. 283. Zob. A. W e 1 t z el, dz. cyt., s. 687 .

83 A. C., t. III. $1654 \mathrm{nr} 55$, s. $281 \mathrm{n}$.

$84 \mathrm{Na}$ synodzie diecezjalnym diecezji wrocławskiej, odbytym $\mathrm{w}$ Nysie w 1653 r. postanowiono wyznaczyć komisarzy w celu skuteczniejszego przejmowania kościołow od protestantow, a dawania ich katolickim księżom. - Statuta synodalia synodi dioecesanae a. 1653 Nyssae celebratae, (5) De ecclesiis desolatis et per haereticos occupatis.
} 
Posiadali już w tym mieście klasztor oo. obserwanci, którzy mimo swej pracy nie mieli żadnych owoców w nawracaniu protestantów na wiarę katolicką.

Odnośnie miejsca założenia placówek misyjnych gubernator sam wyraził swoją propozycję - wymienil mianowicie miasteczko Sławę. Należało ono do dynastii Rechenbergów. Istniało już w 1312 roku. ${ }^{85}$ Sława leżała $27 \mathrm{~km}$ od Głogowa, rozciągała się nad jeziorem Sławskim. Kościół katolicki parafialny zbudowany w XIII w., zagarnęli protestanci w 1524 roku i używali go do 1654 roku. ${ }^{86}$

Ponieważ Sława leżała niedaleko Głogowa, gubernator Fernemond wysłał ojców, by udali się tam w celu zobaczenia na miejscu, jakie są warunki i możliwości założenia placówki. Jedyną intencją hrabiego było, by w Sławie powstała kapucyńska stacja misyjna i by w przyszłości kapucyni wybudowali sobie tam klasztor. W międzyczasie mieli dokonać rekatolizacji miejscowości i okolicy. W tym celu przydzielil hrabia kapucynom cztery parafie. W parafiach tych mieli ojcowie prowadzić duszpasterstwo, zwłaszcza nawracać protestantów na wiarę katolicką. $\mathrm{Z}$ dochodów tych parafii zakonnicy mieli się utrzymywać i budować klasztor.

Ojcowie udali się do Sławy. Byli jednak rozczarowani tym, co zobaczyli. Swoje wrażenia $z$ oględzin opisali $w$ listach do przełożonych o. Jowita i o. Ryszard. Miasteczko było bardzo zniszczone wojną 30-letnią. Znajdowało się $\mathrm{w}$ nim około 20 domów rozrzuconych nad brzegami jeziora. U ludzi nie mogli dostać darmo ani kawałka chleba. Pierwsze oględziny wypadły więc negatywnie.

O. Ryszard skierowal list do o. Grzegorza z Padwy - gwardiana klasztoru we Wiedniu. O. Grzegorz był zarazem definitorem i kustoszem prowincji. W liście tym pisze, że Sławy w żaden sposób nie należy przyjąć. Natomiast myśl zdobyłwania funduszów na budowę klasztcru z dochodów owych czterech parafii uważa za niedorzeczną. O. Ryszand sądził, że w ówcześnie istniejących już klasztorach prowincji było o wiele więcej możliwości służenia Kościołowi, aniżeli tutaj. Nie tylko w Sławie nie podobały mu się warunki życia dla zakonników, ale w księstwie głogowskim w ogóle. Donosi dalej o. Grzegorzowi, że hrabia tylko jeden dzień żywil ich w swym do$\mathrm{mu}$, potem wysłal na kwaterę do klasztoru abserwantów, gdzie wszyscy ojcowie musieli żyć w niewygodzie, nie mieli co jeść ani

${ }^{85}$ Sława - miejscowości o tej nazwie jest cztery; by uniknąć wątpliwosci, o którą z nich chodzi podaję współrzędne geograficzne: pod $51^{\circ} 52^{\prime}$ szerokości geogr. póm. i $16^{\circ} 4^{\prime}$ długości geogr. wsch. od Greenwich. Zob. Słownik geograficzny Królestwa Polskiego. T. X. Warszawa 1889, s. 772. Por. Spis miejscowosci Polskiej Rzeczypospolitej Ludowej. Warszawa 1967 s. 1042.

${ }_{86}$ W. G r a b s k i, 300 miast wróciło do Polski. Warszawa $1960^{\mathrm{s}} \mathrm{s} .388$. Por. A. C., t. III. $1654 \mathrm{nr} 55$, s. 282. Por. Słownik Geograficzny Krolestwa Polskiego, T. X. Warszawa 1889 s. 772. 
gdzie spać. Wobec złych warunków jakie tu zastał, o. Ryszand zwraca się z uprzejmą prośbą do przełożonych o adwołanie go z grupy misyjnej $\mathrm{z}$ powrotem do prowincji. Przy dacie dodal: na wygnaniu głogowskim, dnia 31 lipca 1654 roku. ${ }^{87}$

O. Jowita wysłal dnia 2 sierpnia 1654 roku sprawozdawczy list do o. prowincjała Samuela z Pilsenburga. Co się tyczy miejscowości Slawy, którą w międzyczasie kapucyni zwiedzili, to o. Jowita uważał, że nie ma jakichkolwiek faktycznych podstaw, by można tam zbudować klasztor. O. Jowita usilnie prosil gubernatora o Zieloną Górę. Jednak hrabia życzył sobie by kapucyni zajęli Sławę i dlatego $\mathrm{z}$ inymi sprawami zwlekal nie dając żadnej odpowiedzi. Odnośnie ogólnej sytuacji w księstwie glogowskim - o. Jowita zaznaczył, że ma małą nadzieję na osiedlenje się $w$ tych stronach, gdzie każda miejscowość operacjami wojennymi była niszczona. Ludzie tutaj przez swoje narzekania i przekleństwa więcej go zmęczyli, niż wszystkie inne dotychczasowe trudy i prace. ${ }^{88}$

Misjonarze panowili prośbę u gubernatora o miejscowość Zieloną Górę, w celu założenia w niej placówki zakonnej. Argumentowali, że w mieście tym już pracowali kapucyni. Kontynuowanie pracy misyjnej owych ojców w tym mieście było również życzeniem władz zakonnych. Na propozycję tę zgodził się wreszcie hrabia Fernemond, choć $\mathrm{z}$ długim ociąganiem się, a ksiądz dziekan również przychylił się do prośby kapucynów. 89

Zielona Góra wraz z okolicą stanowiła najbardziej na północ wysuniętą całęść Sląska.90 Była ona oddalona od rzeki Odry $10 \mathrm{~km}$; W XVII wieku miasto przechodziło wiele klęsk żywiołowych i wojennych. W 1627 roku ogromny pożar zniszczył miasto. Spaliło się wówczas 800 warsztatów sukienniczych. W czasie wojny 30-letniej wojska zdziesiątkowały mieszkańców. Podczas wielkiego pożaru w 1651 roku spłonęło całe miasto wraz $z$ ratuszem, kościołem parafialnym, szkołą, szpitalem z kościółkiem i przedmieściami (około 660 domów).

Z początkiem XVI wieku reformacja szybko rozwinęla się. Protestanci zabrali katolicki kościół parafialny i zamienili go na zbór. Od 1542 roku przy kościele byli sami protestanccy pastorzy. ${ }^{01}$

Jak wszystkie niemal kościoły na Sląsku pod panowaniem Habs-

87 A. C., t. III. $1654 \mathrm{nr} 55, \mathrm{~s} .282 \mathrm{n}$.

88 Tamże s. $283 \mathrm{n}$.

89 Tamże s. 282.

90 Miejscowości Grünberg (Zielona Góra) bylo na Sląsku pięć. By nie stwarzało wątpliwości, w której z nich kapucyni byli podaje się współrzędne geograficzne: pod $51^{\circ} 56^{\prime}$ szerokości geogr. półn. i $15^{\circ} 30^{\prime}$ długości geogr. wsch. od Greenwich.

${ }_{91}$ W1. Grabski, 300 miast wrócito do Polski. Warszawa $1960^{8} \mathrm{~s}$. 573-575. Por. Slownik Geograficzny Królestwa Polskiego. T. XIV. Warszawa 1895 s. 599. Por. A. C., t. III. 1654 nr 56, s. 285. Por. Zielona Góra. Przeszłość i teraźniejszosć. Poznań 1962 s. 103. 
burgów, również kościół farny w Zielonej Górze został ostatecznie odebrany protestantom w $1651 \mathrm{rcku}$. Ludność protestancka zmuszona była odtąd albo przyjąc wiarę katolicką albo, w wypadku pozostania przy dawnej wierze, uczęszczać do kościołów położonych poza obrębem Slaska. 92

Nie uległ pożarowi kościół poìożony poza murami miasta pod wezwaniem Sw. Trójcy, a nazywany „Kościołem Polskim”. Nazwa tego kościoła miała historyczne uzasadnienie. $W$ okoliczny ch pięciu wioskach, które należały do Zielonej Góry (Chynów, Łężyca, Przylep, Wolkanów, Zawada) ludność polska była tak liczna, że w końcu XVI wieku powstała kcnieczność założenia cmentarza a także zbudowania osobnego kościoła w celu odprawiania nabożeństw i gloszenia kazań w języku polskim. W 1588 roku założono cmentarz, a budowanie kościola ukonczono w 1590 roku. Kościół byl niewysoki, ściany miał z muru pruskiego z pięciobocznie zakończonym prezbiterium. Pokryty byl stromym dachem gontowym. Na środku dachu znajdowała się mała drewniana wieża z sygnaturką. Wejście do świątyni było ze strony północnej. Oświetlenie w kościele było słabe, gdyż małe prostokątne otwory okienne były wysoko umieszczone. Kościół ten był więc budowlą prostą i skromną. Pierwszym duchownym protestanckim był od roku 1594 Jan Ramicki. Nazywano ich odtąd "Polskimi Diakonami" w odróżnieniu od niemieckich pastorów, rządców parafii Zielonej Góry.

Katolicy w 1651 roku odebrali Kościół św. Trójcy ewangelikom i przeznaczyli go na kaplicę cmentarną. Predykant „Polski Diakon”, wyemigrował $z$ miasta. Kościół nie wrócił już nigdy do pratestantów, mimo że gmina wielokrotnie zanosiła prośby do cesarza..$^{93}$

Gdy duchowni protestanccy opuścili Zieloną Górę, rada miejska powołała na katolickiego proboszcza księdza kanonika z Głogowa, Marcina Franciszka Weberskiego. ${ }^{94}$

Hrabia Fernemond udał się do Zielonej Góry wraz z rodziną. Ojcowie $\mathrm{w}$ tym czasie wyjechali $z$ Glogowa drogą wodną. $W$ porcie w pobliżu Zielonej Góry wysiedli. Przed miastem dołączyli się do orszaku gubernatora $\mathrm{i}$ razem $\mathrm{z}$ nim weszli do miasta. Obywatele miasta wyszli licznie na ulice, by zobaczyć pochód. Ojcowie od razu mogli się przekonać, jakie uczucia wzbudził ich widok. Mieszkańcy jawnie i głośno wyrażali swą niechęć z powodu przybycia kapucynów. Zieloną Górę zamieszkiwali przeważnie protestanci. Nienawidzili oni katolickich księży, nie chcieli katolickiej wiary, ani katolickich dogmatów.

92 Zielona Góra. Przeszłość i teraźniejszość. Poznań 1962 s. 166.

$93 \mathrm{H}$. S chmidt, Geschichte der Stadt Grünberg Schles. Grünberg Schlesien 1922 s. 122 n. Zob. Zielona Góra, dz. cyt., s. $171 \mathrm{n}$.

${ }_{94} \mathrm{M}$. Ef $\mathrm{f} \mathrm{n}$ er, Geschichte der katholischen Pfarrei Grünberg in Niederschlesien von ihr Gründung bis zum Jahr 1840. Grünberg 1852 s. 149. 
Z wielką niechęcią przyjęli rbwnież kapucynów katoliccy mieszkańcy miasta. Byli oni przeważnie biedni. W czasie wojny 30-letniej zdziesiątkowani przez liczne wojska, które wielokrotnie przechodzily przez miasto, ograbieni, przez wysokie kontrybuje zubożeni, a zwłaszcza zniszczeni niedawnym straszliwym pożarem, który ogarnął całe miasto i zamienil go w stertę zgliszcz i popiołu; żyli więc obecnie w nędzy. Ludzie ci nie mieli gdzie mieszkać, ani z czego się utrzymać, jak również nie było źródeł zarobku. Oświadczyli więc kapucynom, że przyjęcie ich do miasta jest dla nich bardzo uciążliwe i prawie niemożliwe.

Ojcowie na zamieszkanie otrzymali mały dom spalony i pełen popiołu, całkiem nie nadający się do użytku. Gubernator nie zwracał uwagi na te braki, lecz wydał rozporządzenie, że dom ten przeznacza dla misjonarzy kapucyńskich i nakazał go odremontować ze skromnych dochodów miejskich. Następnie udał się wraz z ojcami za mury miasta, gdzie stał kościół św. Trójcy. Bez pozwolenia miejscowego proboszcza wziął klucze od tego kościoła i wraz z misjonarzami zwiedził go. Po oględzinach zadecydowal, że kościól ten i w pobliżu znajdujący się plac będzie stosowny do założenia klasztoru.

Ojcowie nawet na krótki czas nie mieli gdzie tutaj zamieszkać. Chcial ich na razie gubernator umieścić $\mathrm{w}$ budynku gimnazjum, który stał $w$ pobliżu domu parafialnego. Jednak budynek ten był pozbawiony wszelkich urządzeń. Nie mogli ojcowie w nim zamieszkać bo poza murowanymi fundamentami i ścianami oraz mnóstwem nieporządków po zamieszkałych tu do niedawna bydlętach dom ten nic poza tym nie posiadal.

Gubernatcr po osobistym stwierdzeniu braków, zwrócil się do elity miasta, zwłaszcza do senatorów z rozkazem, by dom ten przygotowali tak, żeby był zdatny do zamieszkania dla misjonarzy. Hrabiemu wreszcie udało się umieścić kapucynów chwilowo u radcy miasta, którego dom wprawdzie był również spalony, ale już odbudowany na tyle, że można było zamieszkać, chociaż z dużymi niewygodami.

Po załatwieniu tych spraw gubernator życzyl sobie, by dwóch ojców zostało w Zielonej Górze. Dwóch pozostałych chciał zabrać $\mathrm{z}$ powrotem do Głogowa. Nastąpiła narada, który $\mathrm{z}$ zakonników gdzie będzie pracował. O. Hilary prosil, by go zostawić w Zielonej Górze, gdyż źle się czuł jeszcze po ostatniej podróży. Drugi mial zostać o. Elzeary. Natomiast o. Jowita i o. Ryszard mieli przebywać w Głogowie.

Po ustaleniu tych spraw hrabia wrócił do Głogowa, a wszystkich czterech kapucynów zostawil w Zielonej Górze. Dwóch z nich miało czekać na stosowną okazję, by udać się z powrotem do Głogowa.95

95 A. C., t. III. $1654 \mathrm{nr} 56$, s. 285-286.

15 - Prawo Kanoniczne Nr $3-4 / 75$ 
Ledwie gubernator wyjechał z Zielonej Góry pozostawiając samych kapucynów, zaraz złożył im wizytę miejscowy proboszcz wraz $z$ kantorem. Po pierwszym niby przyjaznym pozdrowieniu nastąpiły natarczywe zapytania: po co ojcowie tu przyszli, jaką powagą żądali kluczy od kościola. Pytał skąd ojcowie posiadają jurysdykcję kościelną. Dowiedział się od przełożonego, że gubernator głogowski będąc ostatnio w Zielonej Górze pozwolił kapucynom w kościele parafialnym odprawiać msze św., słuchać spowiedzi ludzi świeckich. Zgodnie z pozwoleniem gubernatora ojcowie mogli codziennie w swoim kościele św. Trójcy odprawiać msze św., a dla spowiadających się, którzy się do nich udadzą, adprawiać nabożeństwa ekspiacyjne. Te informacje proboszcza tak zdenerwowaly, że rozgniewal się jeszcze bardziej. O. Jowita próbował go uspokoić i na wszystkie pytania chciał spokojnie odpowiedzieć. Jeśli proboszcz ma wątpliwości, skąd tu i w jakim celu kapucyni przybyli, powinien zapytać się o to gubernatora. Co się tyczy kluczy do kościoła nie żądali ich kapucyni, lecz sam gubernator. Do kościola weszli kapucyni tylko w towarzystwie hrabiego Fernemond. Jeśli więc ma pretensje, że stała się jakaś szkoda dla autorytetu proboszcza lub jego jurysdykcji, powinien satysfakcji szukać nie u kapucynów, lecz u gubernatora.

Wszystkie te argumenty nie uspokoiły proboszcza. Zabronil ojcom na przyszłość uczęszczać do kościoła im przeznaczonego i w żaden sposób nie zezwolił im na odprawianie mszy św.

Bylo to dnia 9 sierpnia w wigilię św. Wawrzyńca męczennika. Prosili więc ojoowie, żeby przynajmniej nazajutrz, w święto nakazane przez Kościól, mogli mszę św. odprawić. Nie pomogły żadne prośby. Proboszcz nie pozwolil na odprawienie mszy św. i zażądał oddania kluczy od kościoła.

10 sierpnia wczesnym rankiem ojcowie udali się do przeznaczonego im kościoła. O. Jowita wziąl ze sobą dokumenty. Proboszcz czekał już na nich przed kościołem i odmówił wejścia do świątyni. O. Jowita staral się go uspokoić i pokazal papiery, na które proboszcz poprzedniego dnia nie chcial nawet patrzeć. Były to pisma od cesarza, przełożonych zakonnych, biskupa Liescha, od dziekana z Glogowa. $Z$ dokumentów tych dostatecznie jasno widać było skąd misjonarze są i po co przyszli, oraz kto im na przebywanie w Zielonej Górze pozwolił. Proboszcz brał każdy dokument do ręki odczytywał i wreszcie wszystkie adrzucił. Tym większym gniewem zapłonął stwierdziwszy, że żadne $\mathrm{z}$ tych pism nie jest do niego adresowane. Papiery oddał o. Jowicie i do kościoła wejść nie pozwolił.

Wówczas o. Jowita zacząl go prosić, by tylko w tym jednym dniu uroczystego święta mógł mszę odprawić, żeby choć ten jeden raz pozwolił wejść do kościoła.

Wzruszony tymi prośbami proboszcz wpuścił ojców do świątyni. Byl obecny w czasie mszy św., potem towarzyszył im aż do wyjścia 
i zapowiedział, że na przyszłość nie wolno im wchodzić do kościoła. Kapucyni podziękowali za pozwolenie odprawienia mszy św. i odeszli ${ }^{96}$.

Po przybyciu do siebie ojcowie naradzili się, co im dalej czynić wypada $\mathrm{w}$ tak trudnych warunkach. Postanowili zostawić na miejscu o. Hilarego i o. Ryszarda, natomiast o. Jowita wraz z o. Elzearym poszli do Głogowa. Przełożony natychmiast udal się do gubernatora $\mathrm{i}$ opowiedział mu o całym zajściu $\mathrm{z}$ proboszczem $\mathrm{w}$ Zielonej Górze. Gubernator wezwal do siebie księdza dziekana, który był zarazem komisarzem do spraw duchownych na terenie księstwa glogowskiego. Opowiedział o niewłaściwym zachowaniu się proboszcza, obrazie cesarskiego majestatu i księcia biskupa wrockawskiego. Uznał też, że proboszcz przez to zasłużył na surową karę i żądał, by ksiądz dziekan wymierzył mu odpowiednią pokutę, by na przyszłość nie było podobnych występków.

Ksiądz dziekan obiecal gubernatorowi zalatwić sprawę tak, by miał pełną satysfakcję. Zwrócił się również do o. Jowity, by misjonarze nie upadali na duchu i nie zrażali się przykrościami.

Ksiądz dziekan kazał o. Jowicie udać się na drugi dzień do Zielonej Góry, a sam obiecał, że na trzeci dzień tam pojedzie. W umówionym dniu w Zielonej Górze w obecności o. Jowity i proboszcza ksiądz dziekan załatwił sprawy tak, by na przyszłość nie było wątpliwości i powodów do nieporozumień.

Został więc określony stan prawny i funkcje kapucynów. Do użytku otrzymali misjonarze kościół w Zielonej Górze pod wezwaniem św. Trójcy. W kościele tym mogli odprawiać codziennie msze św., spowiadać i innych sakramentów św. udzielać ludowi. W niedziele i święta w godzinach popołudniowych mieli głosić kazania, wykładać naukę katolicką oraz uczyć lud prawd wiary.

Ponadto ks. dziekan przekazal kapucynom dwie sąsiednie parafie, odebrane pastorom, do administrowania, ze wszystkimi prawami parafialnymi. $Z$ dochodów płynących $z$ tych parafii mieli się utrzymywać. O. Hilary miał pracować w Zielonej Górze, natomiast o. Elzeary miał na przemian co drugą niedzielę udawać się do sąsiednich parafii, aby tam pelnić służbę Bożą.

Zanim kapucyni zdobędą środki na wybudowanie własnego mieszkania, mieli zamieszkać $\mathrm{w}$ domu senatora, a za pożywienie płacić $\mathrm{z}$ dochodów otrzymywanych $\mathrm{z}$ parafii.

O. Jowita $z$ o. Ryszardem wrócili do Głogowa według umowy $z$ hrabią Flernemond ${ }^{9}$.

W Głogowie udal się o. Jowita do gubernatora, by ostatecznie załatwić sprawę budowy klasztoru. Miał on stanąć w miasteczku Sława. Udali się więc tam o. Jowita $\mathrm{z}$ o. Ryszardem, by na stałe za-

${ }^{96}$ A. C., t. III. $1654 \mathrm{nr} 57$, s. $286 \mathrm{n}$.

${ }^{97}$ A. C., t. III. 1654 nr 58, s. $287-289$. 
mieszkać. Sława, jak już wspomniano, była miasteczkiem bardzo biednym, liczącym zaledwie 30 rodzin; zupełnie pozbawionym murów, wałów i wież obronnych. Rodzin katolickich było tylko trzy, poza tym ludność wyznania luterańskiego. Miejsce to i ludność aktualnie podlegały dzierżawie. Dochody z tej dzierżawy gubernator przeznaczył na utrzymanie kapucynów. Zamieszkać mieli ojcowie $\mathrm{w}$ domu, w którym dotąd mieszkał pastor. Pastor niedawno opuścił miasto. Misjonarze dom zastali zupełnie pusty.

Obowiązkiem misjonarzy było w niedzielę i święta głosić kazania do ludu, lecz w kościele było zaledwie siedem osób ${ }^{98}$. Wszyscy inni mieszkańcy miasteczka udawali się do swych luterańskich zborów. Żadnymi namowami ani nawet siłą nie dali się nakłonić do słuchania kazań katolickich. Ta zdecydowana i mocna postawa luteran napełniała kapucynów troską i smutkiem. Ze swego pobytu w Sławie nie widzieli nadziei lepszych owoców na przyszłość. O. Ryszard z powodu nadmiernie trudnych warunków zachorował. Mimo zażywania lekarstw do zdrowia nie wracał. Pobyt jego w Sławie stal się bardzo uciążliwy i trudny.

W Sławie o. Jowita poczynil podsumowania swoich spostrzeżeń dotyczących ziemi śląskiej. Przemyślal tutaj, które miejscowości nadają się do założenia klasztorów, a z których należy zrezygnować. Zdecydował, że trzeba starać się o Prudnik, Nysę i Wrocław. Szczególnie silne wrażenie zrobilo na nim i jego towarzyszach nadzwyczaj uprzejme przyjęcie $w$ tych miastach. Tym większe miało to znaczenie na wybór tych placówek, im trudniejsze były warunki bytowania w Głogowie, Zielonej Górze i Sławie. Napisal więc list do gubernatora 28 sierpnia 1654 roku, w którym oznajmil, że dotąd czekali w Sławie na księdza dziekana, by ich tu wprowadzil w posiadanie. Zaznaczył o. Jowita, że jego obowiązkiem jest zdać sprawozdanie przełożonym ze spraw tyczących misji na Sląsku. Miał właśnie okazję przesłać informacje przez obywatela tego miasta, który wybierał się na Morawy. Już w tym liście nadmienił, że trudno będzie $\mathrm{w}$ tych warunkach utrzymać zakonników i założyć na stałe placówki zakonne ${ }^{99}$.

Ponieważ żadne informacje od gubernatora $z$ Głogowa nie nadchodziły, ani ksiądz dziekan nie przyjeżdżal, o. Jowita zdecydowal nie pominąć okázji i dnia 31 sierpnia 1654 roku napisał do prowincjała list sprawozdawczy. W liście tym oprócz opisu tego, jakie placówki otrzymali i jaką mieli pracę misjonarze, szczególny nacisk położył na trudne warunki życia, zwłaszcza w Sławie. $Z$ powodu braku katolików zmuszeni byli żyć z luteranami, ci zaś ani nie chcieli słyszeć o koniecznych potrzebach zakonników.Traktowali ich według kaprysu. Przez ten czas ledwie kilkakrotnie otrzymali trochę

98 M. E f f n e r. dz. cyt., s. $153 \mathrm{n}$.

99 A. C., t. III. 1654 nr 59, s. 289 n. 
zimnej zupy. Pisał o. Jowita, że o. Ryszard wszystkimi sposobami starał się nakłonić go do wyjazdu stąd, jednak zrobić tego nie mogli, gdyż nie mieli w tej sprawie żadnej instrukcji.

W niewielkiej odległości od Sławy biegła granica państwa polskiego. Wypędzeni predykanci ze Sląska tam się schronili i rozpoczęli aktywną działalnaść duszpasterską. O. Jowita pisał, że nie ma nadziei owocnej pracy. Luteranie na kazania nie przychodzili. A zmuszać ich nie można było. Mieszkańcy otwarcie sprzeciwiali się misji kapucynów. Kończąc o. Jowita donosił, że nie widzi jakichkolwiek możliwości zbudowania klasztoru w ówczesnym czasie w całym księstwie głogowskim ${ }^{100}$.

Również o. Ryszard skorzystał z okazji, by wysłać 31 sierpnia $1654 \mathrm{r}$. list do prowincjonała. Na wstępie zaznaczył, że napisał już dwa listy $i$ dotąd nie otrzymał żadnej odpowiedzi. Ma jednak nadzieję, że może tym razem zostanie wysłuchany. Prócz tego, co podał o. Jowita, o. Ryszard w swym liście dodał wiele nowych informacji. Proboszcz w Sławie był bardzo młody. Do kościola kapucynów wpuścil i pozwolił im mszę św. odprawiać. Często jednak powtarzal, że jak będa tutaj misjonarze, to jego pobyt $w$ tej parafii jest zbyteczny 101 .

Co się tyczy utrzymania przeznaczono ojcom trzy parafie, do których dotarcie w porze zimowej było możliwe tylko wozem. Dochód z tych parafii wynosil 50 talarów. $Z$ tego ojcowie mieli się wyżywić i kupić wszystko, co konieczne do życia. Hrabia Fernemond uznał, że są to fundusze niewystarczające, dlatego dodal trochę $\mathrm{z}$ własnych dochodów. O. Ryszard uważał, że na próżno w Sławie przebywaja, ponieważ protestanci posiadają liczne przywileje. Wolno im bowiem chodzić do sąsiednich predykantów, słuchać tam ich kazań, komunikować się, chrzcić dzieci, zawierać związki małżeńskie. W swoich więc praktykach religijnych mają całkowitą swobode. Stąd prosty wniosek, że nikt nie przyjdzie do misjonarzy, nie tylko na prywatną rozmowę, ale nawet do kościoła na kazanie. Protestantów do zmiany wiary nie można było nakłaniać, ponieważ ostatnio cesarz na nowo zatwierdził im wszystkie ich żądania. O. Ryszard postawił pytanie: cóż więc jeden zakonnik poza klasztorem mial tam robić, jeśli nie było innych poważnych racji poza życzeniem hrabiego Fernemond? Przebywanie w Sławie spowoduje szkodę dla dyscypliny zakonnej, jak również dla samych zakonników. Przy końcu listu o. Ryszard usilnie prosił, po raz już trzeci o odwołanie go do prowincji 102.

O. Jowita byl zmęczony i skłopotany wszystkimi trudnościami ostatnich kilku miesięcy. Chciał jak najprędzej doprowadzić do końca dzieło wyprawy misyjnej na Sląsku. Uznał więc, że będzie

100 A. C., t. III. $1654 \mathrm{nr} 61$, s. 292-295.

101 M. Effner, dz. cyt., s. 154.

102 A. C., t. III. 1654 nr 60, s. 290-292. 
stosowniej i roztropniej zrezygnować z placówki w Sławie niż odwlekać na dłuższy czas przyjęcie tak dogodnych fundacji, jakie proponowal biskup Baltazar Liesch.

Zagrożenie utracenia fundatora stwarzal fakt, że biskup był już starcem. Należało liczyć się $z$ ewentualnością, że w wypadku śmierci biskupa założenie klasztorów w Prudniku, Nysie i Wroclawiu może być wówczas dopnowadzone do skutku dopiero po pokonaniu dużych trudności, lub zgoła udaremnione.

Z Nysy napisali o. Jowicie dwaj pozostawieni tam ojcowie Elizeusz i Ezechiel o nowym planie biskupa Liescha. Gdy bowiem dowiedział się, że kapucyni mieli legat na parcelę pod budowę klasztoru we Wrocławiu $\mathfrak{i}$ pewien fundusz na ten cel wyznaczony, powziął myśl zrealizowania tego zamiaru padjętego przez zmarłego generala Kanola Hannibala z Dohnau. Tak więc do swych dotychczasowych życzeń wystawienia dwóch klasztorów w Prudniku i Nysie wyrazil jeszcze wielką chęć zbudowania klasztoru we Wroclawiu 103.

O. Jowita napisał list ze Sławy do gubernatora 1 wirześnia 1654 roku, w którym donosił, że ojcowie pozostawieni w Nysie napisali $\mathrm{mu}$, że jego obecność jest tam nieodzowna. Dlatego postanowił drogę swoją odbyć przez Zieloną Górę, a następnie udać się do Nysy, by zobaczyć się z ojcami Elizeuszem i Ezechielem. W Nysie będzie oczekiwał na dyrektywy od przełożonych, co czynić na przyszłość 104.

Jednak anj od prowincjała anj od gubernatora do Sławy listy nie przychodziły. Wysłał więc o. Jowita 3 września 1654 roku drugi list do gubernatora $z$ oznajmieniem o opuszczeniu Sławy. Swoją decyzję umotywował tym, że mimo oczekiwania odpowiedzi nie otrzymał, dlatego uważal, że może zastosować powszechnie przyjętą regułę, która mówi: jeśli kto milczy można sądzić, że się zgadza. Oznajmil gubernatorowi, że wraz z o. Ryszardem zdecydowali się zrzec prac u dziekana i prepozyta. Podjęcie zobowiązania obsłużenia dwóch odległych parafii, było niewątpliwie rzeczą bardzo trudną, do wykonania której nie czuli się na siłach. Prócz tego przebywanie w Sławie kapucynów było nieużyteczne. „Jestem pewny - pisał o. Jowita - że nasi wyżsi przehożeni nigdy na to nam nie zezwolą, ani ja chcąc być w porządlku w sumieniu nie mogę zobowiązać się do pracy tutaj". O tyle hrabia Fernemond mógł liczyć na zgodę wyższych przełożonych zakonnych, o ile oferował takie placówki, na jakie mieli zapotrzebowanie kapucyni. O. Jowita oświadczył ponadto, że w wypadku, gdyby ojcorwie w Zielonej Górze chcieli pozostać, nie będzie im przeszkadzał w dziele, które rozpoczęli 105.

$\mathrm{Na}$ dzień 17 września udał się o. Jowita z o. Ryszardem do Gło-

${ }^{103}$ A. C., t. III. $1654 \mathrm{nr} 61$, s. 292 n. i tamże nr 62, s. 295.

${ }^{104}$ Tamże nr 62, s. 295.

105 A. C., t. III. $1654 \mathrm{nr} 63, \mathrm{~s} .296$. 
gowa, aby móc zyskać odpust zupełny w kościele oo. franciszkanów z okazji uroczystości otrzymania stygmatów przez św. Franciszka.

Wiadomości, które napływały do zarządu prowincji do Wiednia od grupy misyjnej ze Sląska, wykazywały, że w księstwie głogowskim są trudne, wprost bezandziejne warunki bytowania. Natomiast sprawozdania o stanie rzeczy z Prudnika, Nysy i Wrocławia stawiały sprawy założenia klasztorów w jak najlepszym świetle. Dlatego też prowincjał powziąl decyzję, w których miejscowościach śląskich należy starać się o założenie klasztorów, a z jakich należy zrezygnować. List $w$ tej sprawie wysłał do przełożonego grupy misyjnej na Sląs$\mathrm{ku}$.

Dnia 18 września 1654 roku otrzymal o. Jowita w Głogowie tak długo oczekiwany list od prowincjała. Prowincjał o. Samuel z Pilzenburga pisal, że ponieważ ludność $\mathrm{w}$ księstwie glogowskim była protestancka, a na skutek przywilejów, które posiadała, nie widać możliwości ani nadziei, aby ich nawrócić, nie mogą tam kapucyni pracować bez szkody dla swojego powołania. Na mocy tego pisma prowincjał upoważnił i nakazal pożegnać w sposób taktowny wszystkich w księstwie glogowskim. Następnie mają udać się do Nysy i tam czekać na dalsze dyspozycje. Resztę pozostawił dojrzałemu sądowi i roztropności o. Jowity $\mathbf{1 0 6}$.

O. Jowita wrócil do Sławy $z$ o. Ryszardem i wystosował list do hrabiego Fernemond, w którym poinformowal go, że otrzymal nakaz od prowincjała, by się udał do Nysy. Prosił więc hrabiego, już po raz trzeci, o zezwolenie na tę podróż. Nie czekając na odpowiedź od gubernatora udali się ojcowie ze Sławy do Zielonej Góry, by przebywającym tam misjonarzom przeczytać decyzję prowincjała i dokonać wspólnie narady. O. Jowita sprawę wyjazdu z księstwa głogowskiego pozostawił do osobistej decyzji ojców, gdyby chcieli razem z nim wyjechać do Nysy i tam wspólnie oczekiwać na rozkazy, gdzie się dalej udać. Ojcowie życzeniu prowincjała nie sprzeciwiali się. O. Elzeary i o. Hilary misjonarze z Zielonej Góry wypowiedzieli jednak swoje zdanie. Mówili, że nagły wyjazd wywoła $\mathrm{z}$ pewnością zdziwienie wśród mieszkańców, którzy widzieli z jakim trudem i za cenę jakich przy̆krości kapucyni zdobyli placówkę misyjną w Zielonej Górze. Mieszkańcy mogą mieć podejrzenie i snuć domysły, oraz wysuwać zarzuty z powodu takiego nagłego wycofania się $z$ pracy apostolskiej. Jednomyślnie więc powzięto decyzję by ojcowie, którzy pracowali dotąd w Zielonej Górze pozostali dłużej, dopóki nie otrzymają ostatecznego orzeczenia od prowincjała. O. Jowita $z$ o. Ryszardem mieli się udać z powrotem do Sławy, gdzie mieli oczekiwać na odpowiedź od gubernatora.

Wkrótce hrabia Fernemond wezwał do Glogowa o. Jowitę i w ciągu dwóch dni prowadził z nim rozmowy na temat misji kapucynów

106 Tamże s. 297. 
na Sląsku. O. Jowita podziękował gubernatorowi za trud i zainteresowanie się zakonem kapucynów. Po znalezieniu okazji dnia 21 września wyjechał do Wrocławia ${ }^{107}$.

Zarząd prowincji kapucynów we Wiedniu postanowił zebrać szersze informacje na temat założenia nowych placówek na Śląsku. W tym celu prowincjał zasięgnął rady o. Franciszka ze Sląska, przebywającego w Styrii. O. Franciszek pracował już na Sląsku (1629-1631). Wysłano mu więc odpisy listów, jakie ostatnio przyszły od misjonarzy i proszono, by wydał swoją opinię w tej sprawie. O. Franciszek dnia 22 września $1654 \mathrm{r}$. dał listownie odpowiedź. Uważał on, że należało całkowicie opuścić księstwo głogowskie, a przyjąć miejscowości: Prudnik oraz Nysę i to jak najprędzej, biorąc pod uwage wiek biskupa Liescha. Gdyby bowiem zmarł załowaliby kapucyni swojej zwłoki i chyba później nie znaleźliby drugiego takiego protektora.

Donosił o. Franciszek, że w 1630 roku przywędrował do Wrocławia. Widział miejsce na budowę klasztoru ,położenie za miastem $\mathrm{w}$ pobliżu mostu na Odrze, zwanego potocznie Piaski. Na plac budowy były przywiezione materialy takie jak: kamienie, piasek, budulec. Senat w czasie wojny uży tego materiału do budowy fortyfikacji, za wiedzą i zgodą burgrabiego z Dohnau. Senat wrockawski dobrowolnie zobowiązał się, że zwróci materiały w dwójnasób, gdy nastanie pokój i dojdzie do budowy.

Radził o. Franciszek - gdyby tylko było możliwe - aby zamiast klasztoru w Nysie zacząc budowę we Wrocławiu. Dlatego podsuwał myśl prowincjałowi, by jeszcze przed zimą wysłał do Wrocławia o. Cezarego i o. Jowite w celu zwizytowania oznaczonego miejsca i ostatecznego zbadania jaki jest stan faktyczny 108.

Po rozważeniu więc wszystkich warunków i możliwości na Sląsku definitorium prowincjalne uchwaliło, by przychylić się do próśb biskupa Liescha i założył w Prudniku hospicjum a $\mathrm{w}$ przyszłości klasztor. Na pierwszego przełożonego w Prudniku wyznaczono o. Jowitę. Do pomocy dodano mu o. Elzearego, o. Ezechiela i braci konwersów Michała i Grzegorza. Natomiast ajców Elizeusza, Hilarego i Ryszarda odwołano do prowincji.

We Wrocławiu o. Jowita otrzymał listy od prowincjała, w których zawarte były decyzje definitorium prowincji 109.

Wiadomości $z$ Wiednia ucieszyły o. Jowitę. Wiadomym mu było obecnie czego się trzymać. Opuścił więc pospiesznie Wrocław i dnia 25 września 1654 roku przybył do Nysy wraz ze swoim towarzyszem o. Ryszardem.

107 A. C., t. III. 1654 nr 64 s. 297 n.

108 A. C., t. III. 1654 nr 65 s. 298-300.

109 A. C., t. III. 1654 nr 66 s. 301 n. 
W Nysie o. Jowita wręczył ojcom misjonarzom listy obediencjalne, na mocy których mieli wrócić do prowincji.

Dnia 4 października 1654 roku wszyscy czterej ojcowie udali się $\mathrm{w}$ Nysie do oo. obserwantów, aby uzyskać odpust $z$ okazji uroczystości św. Franciszka, po czym nastąpiło pożegnanie. O. Elizeusz i o. Ryszard udali się na Morawy. O. Elizeusz udał się do Brna, gdzie miał podjąć obowiązki nad kształtowaniem życia zakonnego nonowicjuszy 110.

O. Jowita z Nysy przesłał sprawozdanie do prowincjała 5 października, w którym donosil, czego dokonał po otrzymaniu jego listów. W sprawie Zielonej Góry oznajmił, że pozostawił tam o. Hilarego i o. Elzearego i nakazal im, by przez zimę pracowali, a to ze wzgledu na wiernych, którzy się już do kapucynów przywiązali. O. Jowita wziąl pod rozwage warunki i stwierdzil, że ojcowie otrzymywali dochód $z$ trzech parafii i stąd dobrze sobie żyli.111

Po pożarze w 1651 roku w Zielonej Górze spadek dochodów parafialnych był tak duży, że nie wystarczył na utrzymanie jednego nawet księdza. Jeszcze w 1654 roku nie było odbudowanej plebanii, w której proboszcz mógłby zamieszkać. Duży brak kapłanów diecezjalnych był powodem, że wiele parafii w okolicy Zielonej Góry było nie obsadzonych. Dlatego proboszcz z Zielonej Góry musial sprawować w nich duszpasterstwo. Trudy dojazdów i skąpy dochód były powodem, że wkrótce po przybyciu kapucynów do miasta proboszcz Franciszek Weberski zrzekł się swego urzędu i wrócił do Głogowa, by podjąc $z$ powrotem obowiązki kanonika. Kapucyni więc zostali, na jego miejsce administratorami parafii w Zielonej Górze i w trzech parafiach wiejskich $w$ okolicy. Jedna $z$ tych miejscowości, które obsługiwali kapucyni była parafia położona $10 \mathrm{~km}$ na południowy wschód od Zielonej Góry o nazwie Drzonków (niem. Drentkau) ${ }^{112}$.

$\mathrm{Na}$ rozkaz cesarski rada miejska w Zielonej Górze Pustą Basztę, stojącą w pobliżu kościoła parafialnego, przerobiła na budynek mieszkalny. W nim otrzymali kapucyni swoją kwaterę, do której przenieśli się $z$ prywatnego domu senatora miasta $\mathbf{1 1 3}$.

Jak na placówkę misyjną mieli kapucyni dogodne warunki. Znośne mieszkanie i dobre wyżywienie. Wystarczyło im funduszów nie tylko na utrzymanie, ale też na zakup dużej ilości papieru i książki $z$ ewangeliami w języku niemieckim ${ }^{114}$. Placówka misyjna w Zielonej Górze stawała się obiecująca, a dla Kościoła Katolickiego była bardzo pożyteczna.

110 A. C., t. III. 1654 nr 67 s. 302.

111 Tamże s. 303.

112 M. E f f n e r, dz. cyt., s. 156.

113 Tamże 156 n. Zob. Zielona Góra, dz. cyt., s. 155 n.

114 M.E $f$ f n e r, dz. cyt., s. 157 . 
Brak kleru diecezjalnego był powodem, że do parafii Zielonej Góry, za pobytu kapucynów, zostały przydzielone następujące okoliczne wsie: Güntersdorf (Zatonie), Lawalde (Racula), Drentkau (Drzoników), Külpenau (Kiełpin), Polnisch $=$ und Deutsch $=$ Kessel (Nowy Kisielin), Jonasberg (Zagórze). Prócz tych miejscowości należały do parafii wsie dawniej przydzielone jak: Schertendorf (Przylep), Krampe (Krępka), Sawade (Zawadka), Kühnau (Chynów), Wittgenau (Wilkanowo), Heinersdorf (Jędrzychów). W miejscowościach Sawade i Heinesdorf były stare drewniane kościoły. Kapucyni objeżdżali wsie, odprawiali Msze św. i pełnili obowiązki duszpasterskie 115. Byli więc tu bardzo potrzeibni.

Do utrzymania wiary katolickiej w księstwie głogowskim, a jeszcze bardziej do rozszerzenia rzymskiej religii i pomnożenia członków Kościoła Katolickiego przez nawracanie niewierzacych najbardziej było potrzeba - kapłanów. Tych zaś mogły dać jedynie zakony. Nic więc dziwnego, że tak gubernator Fernemond jak i katolicy Zielonej Góry i jej okolicy wielką nadzieję pokładali w zakonie kapucynów.

Jednak tę dobrze rozwijającą się akcję rekatolizacji w Zielonej Górze i jej okolicy pokrzyżowały odmienne plany wyższych przełożonych zakonnych.

Do Nysy nadeszły listy od prowincjała, z których dowiadujemy się, że wolą jego jest, by ojcowie całkowicie opuścili księstwo glogowskie i wrócili do Nysy. Z Nysy o. Elzeary miał udać się do Prudnika i podjąć się obowiązku budowniczego tamtejszego klasztoru. Natomiast o. Hilary mial zatrzymać się w Nysie i czekać na dalsze dyspozycje przełożonego prowincjalnego ${ }^{116}$.

Listy te otrzymali ojcowie w Zielonej Górze 17 października. O. Elzeary był zadowolny $z$ tej wiadomości. Mieszkal on $w$ Zielonej Górze z największą niechęcią. Ciężka praca w parafiach, do których w niedziele i święta dojeżdżał, jak również różnice zdań i poglądów $\mathrm{z}$ o. Hilarym stwarzaly dla niego trudne warunki przebywania tam.

O. Hilary natomiast był zdania, że wypełnienie nakazu przełożonych należy odłożyć. Uważał, że skutki likwidacji tej placówki będą ze wszech miar złe. Napisał więc w tej sprawie dnia 17 października 1654 roku list do prowincjała $z$ zapytaniem: $z$ jakim on obliczem ma stanąć przed burmistrzem i radą miejską, by oznajmić im o tej decyzji? Wszak oni dużo kapucynom pomogli w ciężkich staraniach o tę placówkę. Kiedy się już wszystko unormowało i zaistniały znośne warunki życia, nagle sami kapucyni wszystko mają porzucić i odejść. Dla ludu prostego będzie to zgorszeniem, szlachta będzie oburzona, gubernator $z$ pewnością poczyta to jako osobistą zniewagę, a wobec cesarskiego majestatu będzie to wyraźne lekce-

115 O. W o I f f, dz. cyt., s. 88 .

116 A. C., t. III. 1654 nr 81 , s. 314 n. 
ważenie. Zaczęły otwierać się w Zielonej Górze dla kapucynów coraz lepsze widoki pracy misyjnej. Szczególnie gdyby na miejsce ojca Elzearego, który pragnąl wyjechać do Prudnika, przysłać innego kapłana, ze znajomością języka polskiego. W mieście tym bowiem mieli Polacy swój kościół i swego polskiego kapelana, na którego utrzymanie łożyli mieszkańcy 100 talarów. Kapelan ten przerwał głoszenie kazań i udzielanie sakramentów i zamierzał opuścić te strony. Pieniądze chcial dobrowolnie kapucynom oddać, pod warunkiem, że będzie któryś $\mathrm{z}$ ojców spełniał za niego posługę duchową. Chętnie również odstąpiłby trzy wioski i parafie, jeśli tylko kapucyni przyślą tutaj kapłana ze znajomością języka polskiego.

O. Hilary chciał na ochotnika podjąć się w czasie zbliżającej się zimy duszpasterzowania $w$ parafiach za o. Elzearego. Największą prośbą o. Hilarego było, by prowincjał zostawił go w Zielonej Górze na pracy misyjnej. Prosil jeszcze za pośrednictwem pirowincjała, swego gwardianina z Ołomuńca, by mu przysłał jego rękopisy, ponieważ cały czas w Zielonej Górze męczyli się bez książek i rękopisów i nie mieli z czego czerpać materiałów do kazań ${ }^{117}$.

Rozporządzenie prowincjała, które o. Jowita wysłał do Zielonej Góry wywołało nie tylko nieporozumienie między o. Hilarym a Elzearym, lecz także konsternację wśród ludu wiejskiego, w parafiach, które ojcowie obsługiwali, jak również wśród katolickich mieszkańców Zielonej Góry. Ogólnie narzekali na przelożonych zakonnych, i żałowali, że muszą utracić tych duchowych opiekunów. Odwoływano ich w takim czasie, gdy zostało przezwyciężonych tyle wielkich trudności, gdy wszyscy katolicy włączyli się aktywnie do umożliwienia ojcom zamieszkania i utrzymania.

Ponieważ do miasta wprowadzil kapucynów sam gubernator Fernemond w imieniu cesarza, dlatego katolicy, którzy dotąd korzystali z posługi duchowej ojców, zwrócili się 20 października 1654 r. z prośbą do gubernatora, by swą władzą i powaga spowodowal zatrzymanie ojców w Zielonej Górze.

Przypominają gubernatorowi, że sam kapucynów 9 września 1654 roku wprowadził do miasta, ku radości katolików i dobru ich dusz. Na początku roku $1629 \mathrm{w}$ tych tak bardzo niebezpiecznych czasach z żebrzącego zakonu kapucynów pracowali ojcowie w tym mieście, aby zdobywać dusze dla Chrystusa i Kościoła Katolickiego. Współcześnie są czasy znacznie spokojniejsze, niebezpieczeństwo wojny minęło. Władze cywilne zrobiły wszystko, co było w ich mocy, by uczynić znośne warunki życia i pracy dla misjonarzy. Tymczasem to nagle odwołanie po krótkim pobycie, bez podania nawet powodu, wydaje się obrażające. Gdyby ci ojcowie, którzy są w Zielonej Górze, byli gdzie indziej bardziej potrzebni, to mogą ich przelożeni przenieść, ale na ich miejsce niech dadzą innych. List podpisali bur-

117 A. C., t. III. $1654 \mathrm{nr} 82$, s. $315-317$. 
mistrz miasta i radcy $\mathrm{w}$ imieniu wszystkich katolickich obywateli 118 .

Ojcowie w Zielonej Górze odłożyli zrealizowanie decyzji prowincjała. Pracowali nadal gorliwie, czym wzbudzali sobie wśród wiernych coraz większą sympatię.

Katoliccy obywatele miasta zwrócili się do ks. dziekana Baltazara Magiusa z prośbą o wstawiennictwo ${ }^{119}$.

Tymczasem przyszła zima. Trudne warunki terenowe i komunikacyjne powodowały opóźnianie się przesyłek listowych, jak również stwarzały możliwość zagubienia ich w drodze. Do końca roku 1654 ani prowincjał ani o. Jowita nie otrzymali żadnej wiadomości od ojców z Zielonej Góry.

Sprawę utrzymania placówki misyjnej $w$ tym mieście o. Hilary i o. Elzeary pozostawili do załatwienia gubernatorowi księstwa głogowskiego hrabiemu Fernemond i komisarzowi do spraw duchownych tegoż księstwa - ks. Baltazarowi Magiusowi.

Ksiądz dziekan po zbadaniu pracy kapucynów i przekonaniu się o wielkiej użyteczności ojców w Zielonej Górze i okolicy wystosowal 29 stycznia $1655 \mathrm{r}$. list do prowincjała napisany w kwiecistym stylu. Najpierw wyrazil ubolewanie w imieniu obywateli Zielonej Góry, że kapucyni zostali odwołani. Oświadczył, że spodziewał się, iż w przyszłości ów dobroczynny duch niesienia pomocy wiernym, który niegdyś wnieśli ojcowie do tego miasta w pierwszych dniach kontrreformacji, obecnie wyda podwójne owoce. Żaden z księży tego księstwa nie był niechętny ojcom. Ks. dziekan stwierdził, że zasmucili się obywatele katoliccy, gdyż w pomocy duchownej kapucyńskich misjonarzy położyli nadzieję zbawienia swoją i swoich najbliższych. A nagle zostali rozczarowani.

Nadmienił, że uważał za swój obowiązek okazać współczucie obywatelom Zielonej Góry i dopomóc im w ich ciężkim zmartwieniu. Dlatego ośmielił się skierować swą skromną prośbę do prowincjała wraz z wiernymi Zielonej Góry i okolicznych parafii. Spodziewał się, że prowincjał postanowi dla dobra imienia Bożego i użyteczności Kościoła, dla chwały i ozdoby zakonu, na wieczne zbawienie chrześcijan katolików, przynajmniej dwóch ojców tutaj zostawić. Oznajmil również, że wszyscy obywatele Zielonej Góry proszą o o. Hilarego ${ }^{120}$.

Z Głogowa, dnia 30 stycznia 1655 r. nie omieszkał również napisać do prowincjała gubernator Fernemond. On to najboleśniej odczuł decyzję definitorium o odwołaniu kapucynów z księstwa gło-

118 A. C., t. III 1654 nr 83 , s. $317-318$.

110 Zródła podają nazwisko ks. dziekana i komisarza, jedne Magius inne Machius. Przyjąłem brzmienie Magius według dekretów synodu diecezjalnego wrocławskiego odbytego w Nysie w $1653 \mathrm{r}$.

120 A. C., t. III. $1655 \mathrm{nr} 8$, s. 388. 
gowskiego. Postanowienie zarządu prowincji poczytał jako ośmieszenie własnej osoby. Kapucyni przybyli na Sląsk przede wszystkim dzięki jego staraniom i zabiegom $u$ cesarza i zarządu austriackiej prowincji kapucynów. Słusznie spodziewał się, że ich duchowa służba Boża wniesie wiele pożytku w akcji kontrreformacyjnej. Tymczasem prośby gubernatora księstwa opolsko-raciborskiego, hrabiego Hoditza, zostały przyjęte i na budowę klasztoru obrano miasto Prudnik, a Zieloną Górę odrzucono. Takie zachowanie się kapucynów uznał za zniewagę osobistą, oraz za wzgardę usiłowań i trudów swoich, jak również katolików z Zielonej Góry. To co przeżywal hrabia Fernemond przeżywali też wierni, którzy korzystali z kapłańskiej posługi kapucynów.

Natomiast wśród protestantów nastąpiła wielka radość $\mathrm{z}$ powodu tak wielkiego pośpiechu i ostatecznego odwołania kapucynów z Zielonej Góry 121.

Gubernator dołącza jeszcze notatkę, że dwóch ojców zatrzymał w Głogowie z powodu silnych mrozów. Gdy te ustaną, odeśle zakonników do Wrocławia.

$\mathrm{Z}$ powodu zaginięcia kart kroniki prowincji trudno dokładnie odtworzyć dalsze miesiące pracy kapucynów w Zielonej Górze. Jednak na miejsce o. Hilarego i o. Elzearego przysłano o. Melchiora i o. Tobiasza 122. Czy ci dwaj ojcowie znali jezzyk polski i czy pracowali wśród Polaków, trudno stwierdzić.

Prowincjał dnia 20 lutego 1655 roku z Pragi wysłał list do hrabiego Fernemond. W liście tym donosił, że chce podać, jakie motywy były powodem ostatecznego odwołania kapucynów z księstwa glogowskiego pismem z dnia 29 grudnia 1654 roku. Pisak, że replikę na tę decyzję od hrabiego Fernemond otrzymał. Prowincjał tłumaczył się, że decyzję tę nie podjął osobiście, ale byla ona wynikiem narady i zapatrywań całego definitorium. Zarząd prowincji chciałby, żeby gubernator uspokoil swoje myśli i serce i zechciał przyjąć decyzję definitorium jako konieczna. Główną przyczyną wycofania się z ziemi głogowskiej była zbyt duża odległość tych ziem od centrum prowincji. Definitorium uważało, że nie można prowincji zakonnej czynić bardzo rozległą i zakłładać nowe klasztory w dużych odległościach od dotychczasowych. $\mathrm{Na}$ zakończenie prowincjał prosił, by hrabia Fernemond zechciał przyjąc to wytłumaczenie i nie brał za złe kapucynom podjęcia takiej decyzji.

Tegoż samego dnia wysłał prowincjał również list do katolickich mieszkańców Zielonej Góry. Treść listu była podobna jak do gubernatora Fernemond. Dodał jeszcze prowincjał, że nie mógł uczynić zadość życzeniom obywateli miasta i uważał za konieczne odwołanie o. Hilarego, jak również nie mógł na stałe pozostawić ojców

121 A. C., t. III.1655 nr 10, s. 390, 393.

122 M. E f f n e r, dz. cyt., s. 157. 
w Zielonej Górze. Jednak zapewnil ich, że tę miłość, jaką posiadali obywatele do zakonników, będą starali się kapucyni wynagrodzić przez stałą modlitwę do Boga za nimi o pomyślność i błogosławieństwo ${ }^{123}$.

Hrabia Fernemond miał jeszcze nikłą nadzieję, że zarząd prowincji zmieni swoją surową decyzję. Jednak prowincjał wysłał jeszcze jeden list do gubernatora Fernemond $z$ dnia 3 kwietnia 1655 roku, $\mathrm{w}$ którym kategorycznie odmówil zostawienia zakonników $\mathrm{w}$ księstwie głogowskim. List ten gubernator otrzymal 15 maja 1655 roku. Sprawił mu on wielką przykrość. Hrabia zrozumiał, że nie ma już żadnej nadziei, by za swojego życia mógł dokonać dzieła, którego tak bardzo pragnąl, to jest sprowadzenia zakonu katolickiego do księstwa, którym rządzil, w celu krzewienia wiary katolickiej tak bardzo dla niego ukochanej. Zdenerwowanie i gniew na przełożonych kapucyńskich byl tak wielki, że jak sam pisze, przez miesiąc nie był w stanie dać odpowiedzi na ostatnj list prowincjała. Dopiero nadchodząca uroczystość św. Antoniego, do którego żywił szczególną cześć i na skutek modlitw do niego, spowodowała pewne uspokojenie. Hrabia napisał 13 czerwca 1655 roku z Głogowa list do prowincjała, w którym wyraził nie tylko swój żal, ale punkt po punkcie starał się zbić argumenty definitorium kapucynów austriackich.

Pisał gubernator, że doznał wielkiego publicznego wstydu na miarę, jaką można sobie wyobrazić, a to na skutek wycofania się kapucynów z Zielonej Góry. Wszyscy katolicy w księstwie głogowskim pokładali w nüch wielkie nadzieje, że chwała Boża będzie znacznie szerzyla się $\mathrm{w}$ przyszłości dzięki ich pracy. Lecz zobaczyl smutek katolików, a radość protestantów i zmuszony był wysłuchiwać ich szydercze uwagi.

W jakiż to sposób została wynagrodzona gorliwość hrabiego za trudy sprowadzenia kapucynów na Sląsk i jak dalece to odejście nadwyrężyło jego reputację.

$\mathrm{Z}$ powodu odejścia kapucynów nie tylko szydercza radość protestantów sprawiła mu zmartwienie, ale także pogarda katolików, którzy uważali, że w sprawie przybycia kapucynów na \$ląsk wnieśli pewien własny wkład. Spoglądali więc na hrabiego urągliwymi i wzgardliwymi oczyma, że dobre jego intencje w tak krótkim czasie wniwecz obrócono, a on nie potrafil temu zapobiec.

Gubernator i obywatele Zielonej Góry smucili się, że przebywanie kapucynów trwało tak krótki czas, sądzili,że po tym zakonie można było się spodziewać więcej wytrwałości w pracy religijnej.

Hrabia zwrócił uwagę na motywy, jakimi posłużyło się definitonium $w$ celu wyttumaczenia swej decyzji, mianowicie - duża odległość od prowincji. Wszak od Prudnika przez Opole to krótka droga. Z Opola bowiem można było statkiem podjechać prawie pod

123 A. C., t. III. 1655 nr 11, s. 393 n. 
samą Zieloną Górę w ciągu kilku dni. Jeszcze bardziej wygodnie i bliżej będzie, gdy w przyszłości we Wrocławiu stanie kapucyński klasztor. Pięć lub sześć dni podróży mniej lub więcej nie mogło być poważnym powodem, by zakon na samym początku, po przezwyciężeniu wielkich trudności likwidował placówkę. Wszak słyszało się: że zakon seraficki swoją działalnością misyjną objął odległe Indie i inne dalekie kraje świata. Tutaj na dziedzicznych terenach ziem cesarskich, gdzie była tak wielka potrzeba krzewienia wiary, gdy się słyszało, że tu i ówdzie powstają różne klasztory, kapucyni uważali tę miejscowaść za zbyt odległą, by mogli tutaj pracować.

Dawniej w czasach wielkiego niebezpieczeństwa czcigodny o. Franciszek ze swym towarzyszem o. Atanazym, który też zmarł w Zielonej Górze, pracowali tu dla większej chwały Bożej i dla miłości bliźniego. Współcześnie wyslany przełożony misji w sposób wykrętny nie chciał przyjąć tej samej placówki, chociaż czasy stały się spokojniejsze i warunki dużo lepsze.

Pierwszym kamieniem obrazy był w Zielonej Górze proboszcz, który stanął na drodze założenia tu klasztoru. Został on jednak już przeniesiony.

Miasto Zielona Góra wraz z dużą ilością mieszczan pozostanie bez zakonników i to $\mathrm{z}$ powodu kapucynów, których gubernator wraz z magistratem i katolickimi obywatelami miasta przed innymi zakonnikami chcieli ufundować.

Czy więc kapucyni wprowadzą się do dalszych krajów i miast aniżeli Prudnik przyszłość pokaże. Gubernator Fernemond spodziewał się od zakonu kapucynów większej gorliwości misyjnej i większego zrozumienia najważniejszej potrzeby na świecie, jaką jest zbawienie duszy bliźniego. A tymczasem za swoje prace w szerzeniu Kościoła Chrystusowego na Sląsku musiał wycierpieć od kapucynów ciężki cios $\mathbf{1 2 4}$.

Misjonarze kapucyńscy pracowali w księstwie glogowskim przez 8 miesięcy. Od początku września 1654 roku do końca kwietnia 1655 roku. Przez ten okres w Zielonej Górze otrzymali tytułem utrzymania 210 florenów; kwotę jak na owe czasy wystarczającą do godziwego utrzymania.

28 kwietnia 1655 roku ks. dziekan Magius wysłał nowego administratora (parochus vicarius) do parafii Drzonków, Jakuba Ehrenhold, by przejąl od kapucynów obowiązki duszpasterskie 125.

Kapucyni całkowicie wycofali się z księstwa głogowskiego.

Należy zastanowić się, czy słusznie postąpili przełożeni wycofując ojców z Zielonej Góry. Wydaje się, że żadne argumenty, które podawali, nie wytrzymały krytyki hrabiego Fernemond. Definitorium kapucynów prowincji austriackiej wykazało brak zrozumienia, nie

124 A. C., t. III. $1655 \mathrm{nr} 12$, s. 395-397.

125 M. Ef f ner, dz. cyt., s. 157. 
tylko aktualnych potrzeb kościoła, ale nawet potrzeb własnego kraju, w którym mieszkali. W Prudniku można było budować klasztor, a w Zielonej Górze mieć placówkę misyjną i utrzymywać w niej tylu księży, na ilu by aktualnie warunki materialne pozwalały.

Definitorium trzymało się ściśle modelu tradycyjnych ówczesnych klasztorów w państwie austriackim, na terenach nie objętych ani wojną 30-letnią, ani ruchami protestanckimi. Model ten przedstawiał klasztor jako zamkniętą placówkę, z której zakonnicy wychodzili tylko w celu głoszenia kazań, na zaproszenie duszpasterzy diecezjalnych. Mogli również głosić kazania we własnym kościele. Na zdobycie na Sląsku takich placówek nastawił się również o. Jowita.

Jednak rzeczywistość religijna wówczas na ziemiach śląskich była inna. Głównym zadaniem duchowieństwa było dzieło kontrreformacji.

Należy zwrócić jeszcze uwagę na jeden fakt. Prowincjał nie pisal w żadnym ze swoich listów, że nie ma księży do pracy misyjnej. Klasztory były przepelnione nadmiarem zakonników. Ludzi do działalności misyjnej austriacka prowincja kapucynów miała pod dostatkiem. Wkrótce po odwołaniu kapucynów z Zielonej Góry stanęly klasztory kapucyńskie $w$ innych miastach na Sląsku fundowane dla 12 zakonników. Po kilkudziesięciu latach w dużej ciasnocie mieszkało $\mathrm{w}$ każdym $\mathrm{z}$ nich około 30 zakonników. Jednak o placówkę, choćby tylko misyjną, w Zielonej Górze nie starano się juź nigdy.

Jak więc wytłumaczyć różnicę przyjęcia kapucynów w Prudniku a Zielonej Górze i Sławie, chociaż wszystkie te miejscowaści należały do jednej diecezjị? Różnice te bowiem wplynąły znacznie na ostateczną decyzję zarządu prowincji.

Przyczyny były różne. Pierwszą z nich to różnośc księstw. Prudnik należał do księstwa opolsko-raciborskiego. Biskup wrocławski był wówczas równocześnie świeckim władcą tych ziem. Dlatego obywatele chociaż mogli nie doceniać władzy duchownej biskupa, jednak mieli poważanie, a nawet lęk przed władcą świeckim. $Z$ tego też powodu katolicy chociaż należeli do mniejszości wyznaniowej czuli się bezpieczni i pewni w swoich poczynaniach kontrreformacyjnych.

Na sposób przyjęcia kapucynów w Prudniku miała duży wpływ obecność biskupa Liescha i hrabiego Hoditza. Byli to ludzie posiadający zmysł praktyczny. Umieli przeprowadzić rzeczowo swoje plany. A ponieważ obydwaj byli - jak na ówczesne warunki bardzo bogaci i nie szczędzili pieniędzy, by uskutecznić swój plan osiedlenia kapucynów, dlatego ich poczynania były wprost zniewalające do przyjęcia ich propozycji przez zarząd prowincji kapucynów.

Natomiast Zielona Góra i Sława należały do księstwa głogowskiego. Ziemie te były bardziej zniszczone w czasie wojny 30-letniej. Ludność długą wojną religijną była tak udręczona, że nie chciała 
słyszeć o jakichkolwiek zmianach wyznania. Klęski żywiołowe jak pożar w Zielonej Górze - były powodem rozpaczy większości obywateli. Mieszkańcy księstwa głogowskiego byli biedni i przed wszelkimi zmianami, które pociągnęlyby za sobą nowe wydatki, bardzo się bronili. Gubernator Fernemond był człowiekiem niezamożnym i sam miał trudności materialne. Prócz tego był życiowo niepraktyczny. Ofiarował kapucynom to czego w praktyce przyjąc nie mogli, jak np. osiedlenie się w Sławie.

Nie było również w księstwie głogowskim fundatora któryby podjąl się finansowania budowy konwentu. W ówczesnych czasach klasztory i kościoly stawiali fundatorzy. Propozycje więc gubernatora Fernemond, by kapucyni $z$ dochodów obslugiwanych przez siebie parafii, wybudowali klasztor, były nierealne. Wszak w Sławie dochody $\mathrm{z}$ obsługiwanych parafii nie wystarczały nawet na skromne utrzymanie dwóch zakonników.

Kapucyni byli zakonem żebrzącym. Utrzymywać mogli się tylko w takiej okolicy, gdzie bracia zakonni przy pomocy zbierania kwesty mogli zdobyć środki na wyżywienie zakonników. W Sławie i w okolicy tych możliwości nie było. Ale gubernator nie wziął tej akoliczności pod uwagę.

W Zielonej Górze można było założyć w ówczesnych warunkach tylko dom zakonny nie uformowany zwany hospicjum ${ }^{126}$. Nie po to jednak zostali wysłani kapucyńscy misjonarze na Sląsk, by szukać tego rodzaju placówek. Prowincja austriacko-czeska była w okresie rozwoju. Dla dużej ilości zakonników potrzebowano nowych klasztorów. Dlatego zarząd prowincji wyrażal zgodę tylko na takie propozycje, które odpowiadały temu celowi. Hospicja prawnie podlegaly jurysdykcji przełożonego najbliższego klasztoru kapucyńskiego. Odległość więc hospicjum w Zielonej Górze do najbliższego klasztoru była rzeczywiście bardzo wielka. W praktyce zakonu hospicja przyjmowano jedynie w pobliżu istniejących konwentów. Dlatego więc definitorium nie zgodziło się na założenie hospicjum $w$ Zielonej Górze.

\section{Zakończenie}

Próby osiedlenia się kapucynów na Sląsku trwały 25 lat (1629-1654). Przez ćwierć wieku warunki zmieniały się. Początkowo plany osiedlenia się $\mathrm{w}$ upatrzonych miastach śląskich okazały się

126 Klasztor $=$ konwent $=$ dom zakonny kanonicznie erygowany, przez wyższych przełożonych, w którym miało byćc 12 zakonników, klauzura i w chórze odmawiane pacierze kapłańskie.

Hospicjum $=$ dom zakonny kanonicznie nie erygowany $\mathrm{z}$ powodu braku odpowiedniej liczby zakonników i niemożliwości zachowania regularnego życia zakonnego. 
po 25 latach niemożliwe i niedogodne do zrealizowania. Wrocław, na skutek sprzeciwu rady miejskiej - był nieosiągalny. Sława, z braku środków materialnych — niemożliwa do przyjęcia, z Zielonej Góry sami kapucyni zrezygnowali, ponieważ $w$ innym śląskim mieście mianowicie Prudniku były lepsze warunki. $\mathrm{Na}$ asiedlenie się $\mathrm{w} \mathrm{Ny}-$ sie nie było ani zgody rady miejskiej ani definitorium kapucynów prowincji austriacko-czeskiej.

\section{VERSUCHE DER ANSIEDLUNG DES ORDENS DER MINORITEN BRUDER KAPUZINER IN SCHLESIEN IM XVI JAHRHUNDERT}

\section{ZUSAMMENFASSUNG}

Im XVII Jhd. war der Protestantismus die herrschende Religion in Schlesien. Diese Gebiete gehörten zu Osterreich. Im Jahre 1628 initierte Kaiser Ferdinand II die Rekatholisierung Schlesiens. In 1629 zogen Missionare aus dem Jesuitenorden und Kapuziner auf diese Gebiete ein zwecks Vornahme der katholischen Missionen für die protestantische Bevölkerung.

Die Kapuzinermissionare arbeiteten in Gross Glogau, Breslau und in Grünberg. Ihre Tätigkeit dauerte einige Jahre. In Breslau, im Stadtviertel Elbing hatten sie einen Bauplatz und eine bedeutende Menge von Baumaterial für den Bau der Kirche und des Klosters. Im Jahre 1632 wurden die schlesischen Gebiete von protestantischen Militärtruppen besetzt. Infolge des Mangels an Erhaltungsmitteln, als auch infolge der Schutzlosigkeit gegen die Protestanten kehrte ein Teil der Kapuzinerpatres nach Prag zurück.

Im Jahre 1632 wurde P. Balthasar Schetze Pfarrer in Grünberg. Als die protestantischen Truppen Grünbeg besetzt hatten, verliess P. Balthasar die Stadt. Als die protestantischen Truppen von den Abteilungen der katholischen Truppen abgewiesen wurden, kehrte P. Balthasar nach Grünberg zurück und führte eine energische seelsorgerische Tätigkeit bis zum Jahre 1639.

Auf Einladung des Breslauer Bischofs Karl Ferdinand und des Weihbischafs Balthasar Liesch, wie auch der schlesischen Magnaten und auch des katolischen Adels, beschlossen die Ordensbehörden im Jahre 1654 die österreichisch-tschechische Provinz auf die schlesischen Gebiete auszudehnen. Sechs Missionars wurden gesandt um zu erforschen, wie die Möglichkeiten und Bedingungen zur Gründung der Konvente in Schlesien aussehen. In Breslau konnten sie den Bau nicht unternehmen, weil ihnen der Stadtsenat kein Siedelungsrecht erteilte. Ich Schlawa gab es keine Bedingungen und keine Fonds zur Gründung eines Klosters. In Grünberg gründeten die Kapuziner einen sich gut entwickelten Missionsposten. Sie hatten auch Möglichkeiten, für die Zukunft, ein Kloster bei der Trinitätskirche $\mathrm{zu}$ bauen, die sie schon erhalten hatten. Jedoch nach acht Monaten einer segensreichen apostolischen Arbeit wurden die Priester aus Grünberg von ihren Vorgesetzten abberufen. Die Vorgesetzten sahen bessere Bedingungen in einer anderen Stadt Schlesiens, nämlich in Prudnik. Für die Gründung eines Klosters in Neisse erteilte die Verwaltung der österreichisch-tschechischen Provinz keine Zustimmung. Es ist anzunehmen, dass die Missionstätigkeit der Kapuziner durch die Dauer von 25 Jahren grösser war und sich auf eine grössers Zahl von Städten aus- 
dehnte. Der Verlust von vielen archivalischen Quellen während des II Weltkrieges verunmöglicht die Angabe einer genaueren Darstellung.

Die Versuche der Ansiedlung der Kapuziner in Schlesien dauerten ein Viertel der Jahrhunderts. Durch diese Zeit vermochten die Kapuziner nicht, trotz der Anstrengungen seitens des Ordens wie auch der katholischen kirchlichen und weltlichen Behörden, die nötigen Rechte und materielle Mittel für die Gründung eines Klosters zu erwerben. 